\title{
Implicacións da propiedade da terra na planificación e xestión dos espazos protexidos en Galicia
}

Recibido: 20 outubro 2015 / Aceptado: 21 decembro 2015 (c) IBADER- Universidade de Santiago de Compostela 2015
Resumo A titularidade dos terreos incluídos nos espazos naturais galegos foi mudando co paso do tempo. Nas primeiras etapas, os espazos protexidos abranguían áreas de escasa superficie de titularidade ou tutela públicas. A partires da promulgación da política autonómica, o conxunto de espazos naturais protexidos galegos aumentará a súa superficie de xeito espectacular, sobre todo coa posta en marcha da Rede Natura 2000, realizándose este incremento fundamentalmente sobre territorios de titularidade privada. A planificación destes espazos soamente será desenvolvida de xeito heteroxéneo, acumulando prolongados retrasos e conflitos na conservación e xestión dos compoñentes naturais. Dende o ano 2007 ata a actualidade, as declaracións de espazos de iniciativa municipal e privada son as predominantes, executando os correspondentes instrumentos de planificación os propios promotores dos devanditos espazos, amosando unha maior axilidade e eficacia no cumprimento dos prazos que os espazos de tutela autonómica. Neste sentido, na actualidade estanse a configurar novas ferramentas para a xestión e conservación das áreas privadas, como a custodia do territorio, así como se consolidan iniciativas para a declaración de espazos que contribúan á conservación da biodiversidade e a promoción do desenvolvemento sostible, como é o caso das Reservas de Biosfera.

Palabras chave gobernanza, titularidade, ordenación, conservación, protección.

\section{Javier Ferreiro da Costa $\cdot$ Pablo Ramil-Rego}

GI 1934-TB (Territorio, Biodiversidade), Instituto de Biodiversidade Agraria e Desenvolvemento Rural (IBADER), Universidade de Santiago de Compostela, Campus de Lugo s/n, Lugo E-27002, Spain.

E-mail: javier.ferreiro@usc.es.
Abstract The ownership of land included in Galician protected areas was changing over time. In the early stages, the protected areas ranged small areas of public ownership or guardianship. From the enactment of regional policy, the set of Galician protected areas increased its surface dramatically, especially with the implementation of Natura 2000 , being realized this increase mainly on privately owned lands. The planning of these spaces will be developed only so heterogeneous, accumulating long delays and conflicts in the conservation and management of natural components. Since 2007 until today, protected areas promoted by local and private initiative are the predominant declarations, running the corresponding planning instruments made by promoters of these areas. They have showed a greater agility and efficiency in meeting deadlines than public regional guardianship protected areas. In this sense, today new tools are being set up for the management and conservation of private protected areas, such as land stewardship, as well as initiatives to consolidate the statement of spaces that contribute to the conservation of biodiversity and the promotion of sustainable development, as is the case of Biosphere Reserves.

Keywords governance, ownership, ordination, conservation, protection.

\section{Introdución}

Na actualidade, dentro do Estado Español, os espazos protexidos están regulados mediante as disposicións da Lei 42/2007, do 13 de decembro do patrimonio natural e da biodiversidade (BOE $n^{\circ} 299,14 / 12 / 2007$ ). A devandita Lei establece tres grandes grupos de áreas protexidas, en función da súa natureza.

Como Espazos Naturais Protexidos (ENP) quedan configurados os territorios que sexan declarados como tal debido a que conteñen sistemas ou elementos naturais representativos, singulares, fráxiles, ameazados ou de especial interese ecolóxico, científico, paisaxístico, xeolóxico ou educativo. Estes espazos deberán adicarse á 
protección e o mantemento da diversidade biolóxica, da xeodiversidade e dos recursos naturais e culturais asociados. A Lei 42/2007 establece 5 tipoloxías de ENP (Parques, Reservas naturais, Áreas mariñas protexidas, Monumentos Naturais e Paisaxes Protexidas), que en cada Comunidade Autónoma serán complementadas polas figuras que a súa propia normativa estableza. No caso galego, a Lei 9/2001, de 21 de agosto, de conservación da natureza (DOG $\left.n^{\circ} 171,04 / 09 / 2001\right)$, establece como categorías de ENP, ademais das anteriores, aos Humidais Protexidos, as Zonas de Especial Protección dos Valores Naturais (ZEPVN), os Espazos Naturais de Interese Local (ENIL) e os Espazos Privados de Interese Natural (EPIN). Neste sentido, cabe salientar que a Lei 9/2001 creaba ademais a Rede Galega de Espazos Protexidos (RGEP), na que se inclúen todas as categorías de ENP establecidas, salvo os ENIL e EPIN. En definitiva, formarán parte da RGEP aqueles espazos de promoción e tutela do organismo competente autonómico (o cal se responsabilizará de da sua xestión a través do financiamento axeitado), mentres que os espazos xestionados polos entes locais e propietarios privados quedarán excluídos da devandita Rede (e por tanto deberán no seu caso procurar a financiación necesaria para a súa conservación e xestión).

En segundo lugar, a Lei 42/2007 establece os Espazos Protexidos Rede Natura 2000, compostos polas áreas designadas como Lugares de Importancia Comunitaria (LIC) ata a súa transformación en Zonas Especiais de Conservación (ZEC), ao abeiro do disposto na Directiva Comunitaria 92/43/CEE. Tamén se consideran dentro desta categoría, as Zonas de Especial Protección para as Aves (ZEPA) designadas ao abeiro da DC 2009/147/CE. Tanto os LIC, como os ZEC e as ZEPA terán o alcance e as limitacións que as Comunidades autónomas establezan na súa lexislación e correspondentes instrumentos de planificación. En Galicia, estes espazos son declarados baixo a figura de Zona de Especial Protección dos Valores Naturais (ZEPVN), ao abeiro da Lei 9/2001.

Finalmente, a Lei 42/2007 considera un terceiro grupo de figuras de protección de espazos, as Áreas protexidas por instrumentos internacionais, nas que se inclúen todos aqueles espazos naturais formalmente designados de conformidade co disposto en Convenios e Acordos internacionais dos que sexa parte España. Neste sentido, entre as figuras establecidas na Lei $42 / 2007$, dentro do territorio galego foron designadas un total de 3 destas tipoloxías: Humidais de importancia internacional do Convenio de Ramsar (Irán), Áreas protexidas polo Convenio para a protección do medio mariño do Atlántico Nordés (OSPAR), e as Reservas de Biosfera declaradas pola UNESCO.

O conxunto de áreas declaradas ao abeiro das figuras anteriores compoñen o marco no que se deseñan as medidas e ferramentas para manter o estado de conservación do patrimonio natural e a biodiversidade, de xeito que se integren nas políticas sectoriais os obxectivos e as previsións de conservación e valoración do patrimonio natural, a protección da biodiversidade, a conservación e uso sostible dos recursos naturais, e o mantemento da integridade dos ecosistemas. Resulta desexable que as áreas protexidas contribúan, ademais dos seus inherentes obxectivos de conservación, á incentivación de iniciativas privadas de conservación da natureza, ao fomento da educación e información xeral sobre sobre a necesidade de protexer aos tipos de hábitats e especies de interese para a conservación, e en definitiva ao potenciamento da participación pública no proceso de planificación e xestión das áreas protexidas.

\section{Os inicios das políticas de conservación: declaracións de espazos públicos}

A Lei de 7 de decembro de 1916 de Parques Nacionais (Gaceta de Madrid $\left.n^{\circ} 343,08 / 12 / 1916\right)$, é considerada a primeira disposición legal española no que á materia de conservación de espazos protexidos se refire. A súa recepción foi positiva (Hernández Pacheco 1917, Pidal 1917a), xerando un numeroso conxunto de propostas de territorios para formar parte dun Parque Nacional, comprendendo dende territorios senlleiros polos valores albergados, cunha extensión considerable, ata pequenos espazos locais que posuían un valor cultural, relixioso, sentimental ou paisaxístico. Esto motivaba que o marco xurídico fose desenvolvido a través do Real Decreto de 23 de febreiro de 1917 (Gaceta de Madrid n 55, 24/02/1917), establecendo as figuras dos Parques e Sitios Nacionais, de xeito que se diferenciasen os lugares verdadeiramente merecedores de seren Parques Nacionais, daqueles con menor relevancia e que por tanto merecesen ser Sitios Nacionais (Pidal 1917b).

Tamén o Real Decreto de 23 de febreiro de 1917 dispoñía que os distritos forestais elaborasen unha relación dos sitios máis notables que mereceran unha especial protección. A información relativa á devandita relación de sitios notables foi recompilada en diversos traballos tras exhaustivas revisións de expedientes e informes (ICONA 1981, Mata Olmo 1992, Mulero 2002), aínda que non recollen as superficies de cada un dos mesmos, de xeito que non é posible facer unha análise xeo-estatística deste conxunto de espazos. En Galicia chegábase a reunir un total de 17 espazos (ICONA 1981), o que supoñía o $22 \%$ do conxunto total de 76 espazos designados no territorio español, dato significativo tendo en conta que o territorio galego soamente inclúe o $6 \%$ da superficie española.

O denominador común nos 17 sitios notables galegos era o marcado matiz forestal que posuían, probablemente motivado polo organismo que confeccionaba o listado. Neste sentido resulta destacable que unha proporción importante dos mesmos eran montes incluídos no Catálogo de Montes de Utilidade Pública, exceptuados da desamortización, e que viñan sendo obxecto de traballos de repoboación por parte dos Distritos Forestais. Ademais, esta proposta de sitios notables incluía montes moi vencellados ao excursionismo ou ao seu papel como miradoiros ou fitos emblemáticos.

Non obstante, ao abeiro do Real Decreto de 23 de febreiro de 1917 tamén se xeraron un importante número de peticións para designar novos Parques ou Sitios Nacionais, mais unha boa parte das mesmas foi rexeitada por non 
reunir as condicións necesarias. De novo xurdiu a necesidade de procurar unha solución para que esas iniciativas non quedasen no esquecemento, para o cal se promulgaba a Real Orde do 15 de xullo de 1927 (Gaceta de Madrid $\left.n^{\circ} 203,22 / 07 / 1927\right)$, na que se establecerá un maior rigor nas condicións que deben cumprir os espazos declarados Parques Nacionais, mentres que se establecen como figuras complementarias os Sitios Naturais de Interese Nacional (SNIN) e os Monumentos Naturais de Interese Nacional (MNIN). Non obstante, non será ata a chegada da Segunda República Española cando se aproben os primeiros espazos destas categorías en Galicia, baixo a figura de Sitios Naturais de Interese Nacional (SNIN): en 1933 decláranse de xeito conxunto o Cumio da Curotiña, a Estaca de Bares e o Cabo Vilán mediante a Orde de 31 de outubro (Gaceta de Madrid n ${ }^{\circ} 309$, 05/11/1933), e en 1935 serán engadido o Monte Aloia mediante a Orde de 5 de xullo (Gaceta de Madrid n 504 , 13/07/1935)

A petición da declaración da Curotiña como SNIN, formulada dende o Concello da Pobra do Caramiñal, servirá como alicerce para que a Comisaría de Parques Nacionais realice un estudo da zona litoral galega emitindo informe favorable e ampliando con respecto ás outras dúas paraxes (Cabo Vilán e Estaca de Bares), declarándoas igualmente como SNIN (Hernández-Pacheco 1933). Con todo, estes primeiros SNIN galegos serán declarados sobre terreos de titularidade ou tutela pública. O Cumio da Curotiña describirase como "pertencente a monte público, suxeito á intervención do Corpo de Enxeñeiros de Montes". Pola súa banda, o Cabo Vilán inclúe o "promontorio do cabo e o illote situado no seu extremo, comprendendo terreos de titularidade do Estado e dependentes da Dirección Xeral de Obras Públicas". No tocante á Estaca de Bares, o SNIN inclúe "a parte culminante do cabo, sendo paraxe propiedade do Estado e dependente do Ministerio de Mariña, chegando case ata o cumio do monte traseiro onde se sitúa o semáforo marítimo". En definitiva, 3 novos espazos de escasas dimensións (entre os 3 non chegan ás $60 \mathrm{ha}$ ), e declarados en torno a terreos de titularidade pública, para a conservación de miradoiros e lugares de contemplación do litoral galego.

O SNIN do Monte Aloia, pola súa banda, declararase sobre Montes de Utilidade Pública sobre os que o Distrito Forestal viña desenvolvendo dende o ano 1910 labores de repoboación, complementadas pola apertura dun camiño forestal de acceso ao monte e de novos camiños de ferradura, así como a construción dunha pequena presa para usos múltiples: viveiro piscícola, punto de auga para rego ou extinción de incendios, control das avenidas. Sen embargo, as labores levadas a cabo polo Distrito Forestal eran motivo de conflito cos veciños das parroquias ás que pertencían os montes. Estes consideraban que as repoboacións limitaban a súa actividade gandeira, atribuíndoselles a autoría dos numerosos incendios que asolaban aos repoboados no Aloia (Areses 1929, 1931). Non obstante, a actitude dos organismos forestais non eran de gran axuda na resolución do conflito, considerando aos campesiños galegos como "incultos, non intelixentes, males cultivadores e incapaces de aproveitar a labor colectiva"
(Areses 1926, 1953), postulándose as administracións como redentoras da lamentable situación do agro galego mediante a repoboación forestal.

A suma dos 4 SNIN galegos declarados durante a Segunda República abrangue un total de 257,7 ha, o que representará menos do $0,01 \%$ do territorio continental galego. Non obstante, tras a Guerra Civil asistirase a un freo considerable na promoción e publicación de medidas de declaración, xestión e planificación de espazos protexidos en España, chegando a case desaparecer os organismos responsables dos mesmos. Deste xeito, ata finais da década do 1970 non se declararán espazos en Galicia, e apenas en España se producirán adendas ás áreas protexidas.

Durante a década do 1960 asistirase a un tímido cambio con respecto á consideración da sociedade con respecto á natureza, o que motivará que no decenio seguinte xurda unha reforma da administración, creando un organismo específico para a conservación da natureza (o ICONA), e apareza a primeira Lei de espazos naturais protexidos de España, a Lei 15/1975, de 2 de maio (BOE $n^{\circ} 107$, 05/05/1975). Con todo, as actuacións do ICONA non estarán exentas de crítica dende posturas ambientalistas (Fernández \& Pradas 1996), e a Lei 15/1975 será tamén criticada aos anos seguintes da súa aprobación debido ás profundas modificacións ás que se viu sometido o seu articulado dende os borradores iniciais, ata o texto publicado definitivamente (Ortuño 1977, López Ramón 1980, González Aldama 1982, Anglada 1985, ICONA 1981).

Ao abeiro deste cambio de paradigma xurdirán dúas novas declaracións de espazos naturais protexidos en Galicia, agora baixo a nova figura de Parque Natural creada ao abeiro da Lei 15/1975. O primeiro será o Monte Aloia (reclasificación e ampliación do SNIN) mediante o Real Decreto 3160/1978, de 4 de decembro (BOE $n^{\circ} 16$, 18/01/1979), e o segundo serán as Illas Cíes mediante o Real Decreto 2497/1980, de 17 de outubro (BOE n 275, 15/11/1980). Neste último caso, a práctica totalidade do arquipélago son terreos de titularidade pública na súa maior parte (Marcide \& Basanta 1944; Areses 1951, 1953), existindo pequenos encravados de propiedade particular. Por tanto, seguían a promoverse as declaracións de espazos naturais protexidos sobre terreos públicos na súa maior parte. Entre ambos os dous espazos sumarase un total de 1.179,9 ha declaradas, que se sumarán aos SNIN declarados durante a $2^{a}$ República (Figura 1), de xeito que os espazos designados antes da posta en marcha do Goberno autonómico en Galicia abranguerán un total de $1.237,6$ ha,o $0,04 \%$ do territorio galego, a maior parte das mesmas representadas por terreos públicos.

\section{A política autonómica de conservación e a propiedade privada}

A transferencia das competencias en materia de conservación da natureza en fase preautonómica mediante o Real Decreto 167/1981, de 9 de xaneiro (BOE $n^{\circ} 37$, $12 / 02 / 1981)$, e na fase autonómica co Real Decreto 1535/1984, de 20 de xuño (BOE n² 209, 31/08/1984), non 
serviu nun primeiro momento para impulsar as iniciativas en materia de declaración de espazos naturais en Galicia. Con todo, as principais novidades no avance científico iranse incorporando de xeito paulatino ao marco conceptual e estratéxico en materia de protección de espazos protexidos, así como os obxectivos de conservación herdados das normativas en Convenios internacionais dos que formaba parte España, o que provocará a actualización normativa mediante a aprobación da Lei 4/1989, de 27 de marzo, de conservación dos espazos naturais e da flora e da fauna silvestres (BOE $\left.n^{\circ} 74,28 / 03 / 1989\right)$. A integración destas novas tendencias e coñecementos no panorama lexislativo, favorecerán un incremento nas propostas de declaracións de espazos en Galicia, comezando a incluírse superficies significativas de terreos de titularidade privada, tanto colectiva como individual.

A promulgación da Lei 4/1989 introducía novos cambios no

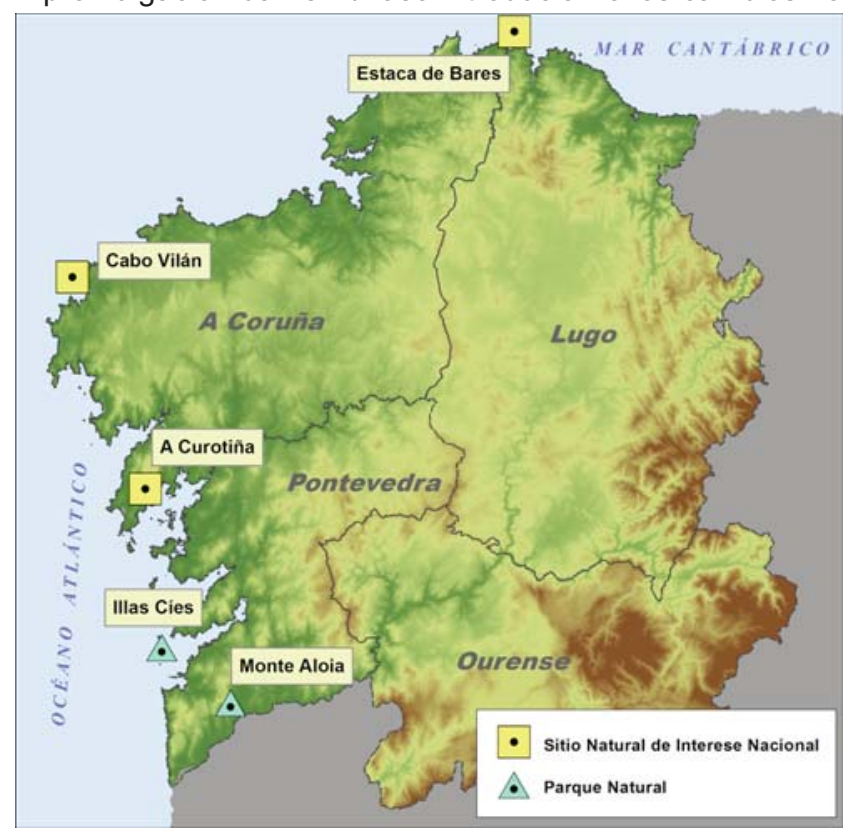

Figura 1.- Situación e categorías dos Espazos Naturais Protexidos declarados en Galicia ata o ano 1980

paradigma dos espazos naturais, tanto na xestión como na planificación dos mesmos. Ao abeiro das competencias que establecía a mesma, promulgábase o Decreto 82/1989, de 11 de maio (DOG no 104, 01/06/1989), polo que se regulaba a figura de Espazo Natural en Réxime de Protección Xeral (ENRPX), que serviría como punto de arranque para as primeiras declaracións de espazos naturais protexidos polo Goberno Autonómico galego. Deste xeito, a partires do ano 1989 realizaranse unha serie de declaracións provisionais de ENRPX, que nalgúns casos derivarían na declaración de espazos dentro das categorías que establecía a Lei 4/1989 (Parques Naturais de Corrubedo e Baixa Limia-Xurés), ou en declaracións definitivas de ENRPX. Como consecuencia, durante o período transcorrido entre os anos 1989 e 1995, en Galicia chegarán a declararse, de forma provisoria ou definitiva, un total de $34.122,4$ ha de novos espazos, que unidos aos xa existentes sumarán un total de $35.360,0$ ha, das que $32.126,4$ ha corresponden a medios terrestres, o que representa o 1,1\% do territorio autonómico continental galego. Nestas superficies inda seguen a incluírse terreos de titularidade pública, como O Invernadeiro (Paül Carril 2009), mais xa comezan a configurarse novas áreas de titularidade privada (Corrubedo, Serra do Xurés, Ortigueira, Cecebre, Umia-O Grove).

A aparición da DC 92/43/CEE, e a súa trasposición ao marco lexislativo español a través do Real Decreto 1997/1995, introducirán o procedemento para a posta en marcha da Rede Natura 2000, rede ecolóxica coherente que debían formar os Estados Membros para o mantemento ou restablecemento nun estado de conservación favorable dos hábitats e especies de interese para a conservación, segundo a representatividade territorial dos mesmos, a partires da mellor información científica dispoñible. A posta en marcha da Rede Natura 2000 provocará un espectacular incremento de novas propostas de Espazos Naturais Protexidos en Galicia, tanto en número como en superficie, xa que os espazos propostos para formar parte da devandita Rede serán declarados provisoriamente como ENRPX, sendo periodicamente revisados e prorrogados: incluirase como ENRPX un $10,6 \%$ da superficie continental galega na proposta de 1999 , un $11,6 \%$ da elaborada en 2001, e un 11,7\% nas modificacións establecidas en 2003. Ademais, seguirán a promoverse novas declaracións de Espazos Naturais Protexidos segundo as categorías da Lei 4/1989, incluíndo novos Parques Naturais (O Invernadeiro, Fragas do Eume), os primeiros Monumentos Naturais galegos (Souto da Retorta, Fraga de Catasós, Souto de Rozabales, Costa de Dexo), e declaracións definitivas de ENRPX. Deste xeito, no ano 2001 a superficie protexida en Galicia multiplicarase por 10 con respecto ao ano 1995 (Figura 2), acadando un total de $372.618,8$ ha, das que $345.613,5$ ha corresponderán con superficies terrestres, o $11,7 \%$ do territorio continental galego.

O importante incremento da superficie protexida en Galicia ocorrido entre os anos 1995 e 2001, fundamentalmente con motivo da posta en marcha da Rede Natura 2000, a través da súa consideración como ENRPX, e logo sendo declarados como ZEPVN, realizaríase na súa maior parte sobre terreos forestais de titularidade privada, tanto colectiva como individual.

A aprobación da Lei 9/2001, de conservación da natureza de Galicia, contemplará o establecemento de novas categorías de Espazos Naturais Protexidos no ámbito galego, en conformidade coa Lei 4/1989: os Humidais Protexidos, as Zonas de Especial Protección dos Valores Naturais (ZEPVN, creada específicamente para a inclusión dos espazos da Rede Natura 2000), os Espazos Naturais de Interese Local (ENIL) e os Espazos Privados de Interese Natural (EPIN). Ao abeiro da mesma, e ata o ano 2007, declararase o primeiro e único Parque Nacional de Galicia (Illas Atlánticas de Galicia), o último Parque Natural ata a actualidade (Serra da Enciña da Lastra) e novos monumentos naturais (Praia das Catedrais, Carballa da Rocha, Serra de Pena Corneira). Tamén se declararán os primeiros espazos ao abeiro das novas figuras establecidas na Lei 9/2001: os ZEPVN correspondentes aos espazos da Rede Natura 2000, o ZEPVN Miño-Neira, a declaración no 
ano 2004 dos 5 Humidais Protexidos correspondentes aos humidais do Convenio Ramsar, e o primeiro ENIL (Voutureira).

Con todo, o aumento da superficie protexida non sería tan elevado como na etapa anterior (Figura 2), posto que a maior parte destas declaracións realizábanse en áreas que foran declaradas previamente baixo a figura de ENRPX, categoría que non constará na Lei 9/2001 e que desaparecerá do panorama de conservación galego en substitución da ZEPVN. Deste xeito, a superficie protexida aumentará en máis de 17.000 ha, acadando por tanto un total de $389.951,2$ ha, das que $351.307,6$ ha se corresponden con medios terrestres, polo que o $11,9 \%$ do territorio galego se atopará incluído dentro dalgunha tipoloxía de Espazo Natural Protexido. A superficie protexida incrementada entre os anos 2001 e 2007 será efectuada tamén sobre terreos de titularidade privada na súa maior parte.

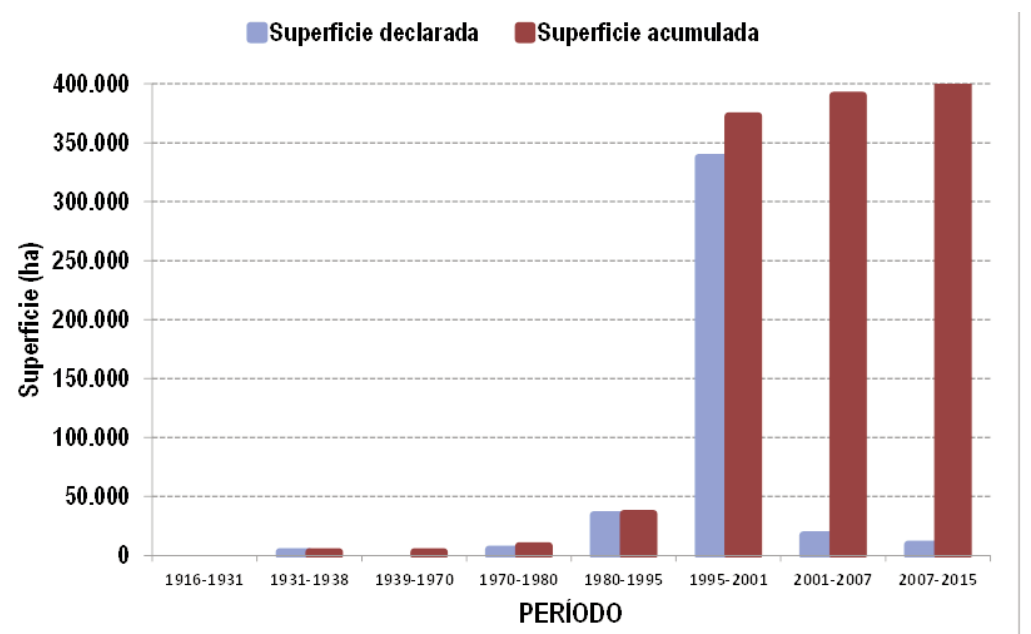

Figura 2.- Evolución temporal das superficies de Espazos Naturais Protexidos declarados en Galicia

A Lei 42/2007 derogará á Lei 4/1989, en resposta á necesidade de adaptación do marco xurídico estatal ao gran conxunto de avances científico-técnicos que xurdiron nos últimos 10 anos do século $X X$ e nos primeiros anos do século XXI. A nova Lei establecerá un réxime xurídico básico de conservación baseado no uso sostible e a mellora e restauración do patrimonio natural e da biodiversidade, establecendo, entre outros instrumentos, tres grandes grupos de áreas protexidas: os Espazos Naturais Protexidos (ENP), os Espazos Protexidos Rede Natura 2000, e as Áreas Protexidas por Instrumentos Internacionais.

No tocante aos Espazos Naturais Protexidos (ENP), seguirán a producirse novas declaracións ao abeiro da Lei 42/2007 e da propia Lei 9/2001: as 2 primeiras Paisaxes Protexidas (Val do río Navea, Penedos de Pasarela e Traba), 7 novos ENIL (Puzo do Lago, Illas de San Pedro, Xunqueira de Alba, Loio-Ruxidoira, Vao-Baluarte, Río Gafos, Praia América), o primeiro EPIN (Sobreiras do Faro), un novo Monumento Natural (Campodola-Leixazós) e unha nova ZEPVN (ZEPA A Limia), así como se modifican as delimitacións dos 5 Humidais Protexidos declarados no ano 2004, e se amplía a superficie do Parque Natural da Baixa Limia - Serra do Xurés. Todo esto traducirase nun aumento efectivo da superficie protexida en máis de 9.000 ha dende o ano 2007 , polo que o incremento de superficie protexida redúcese case á metade con respecto ao período anterior (Figura 2), debido a que os novos espazos a incluír son de reducidas dimensións, mentres que as ampliacións e modificacións realízanse sobre áreas que xa posúen a condición de Espazo Natural Protexido, mais noutra categoría, polo que apenas aportan novas superficies protexidas no conxunto autonómico.

En consecuencia, a superficie abranguida polos Espazos Naturais Protexidos galegos ascende a 399.216,0 ha, das que $360.569,4$ ha son medios terrestres, o $12,2 \%$ da superficie continental galega. Do total da superficie, soamente o $5,3 \%$ se inclúe sobre terreos de titularidade pública, de xeito que o $94,7 \%$ restante está delimitado sobre terreos de titularidade privada (Figura 3), xa sexa individual (o $52,9 \%$ ) ou colectiva (o $41,8 \%$ ). As ZEPVN son as tipoloxías de espazos que aportan a maior parte da superficie dos Espazos Naturais Protexidos declarados en Galicia (Táboa 1): o 98\% da superficie declarada como ENP inclúese, cando menos, nunha ZEPVN.

\section{A planificación na Rede Galega de Espazos Protexidos}

\section{A planificación baixo a Lei 4/1989}

Coa promulgación da Lei 4/1989, ademais de diversos cambios nas categorías de protección, xurdirán importantes modificacións no panorama da planificación das mesmas, materializados no establecemento dos Plans de Ordenación 
dos Recursos Naturais (PORN) e dos Plans Reitores de Uso e Xestión (PRUX), como instrumentos de planificación dos recursos a protexer.

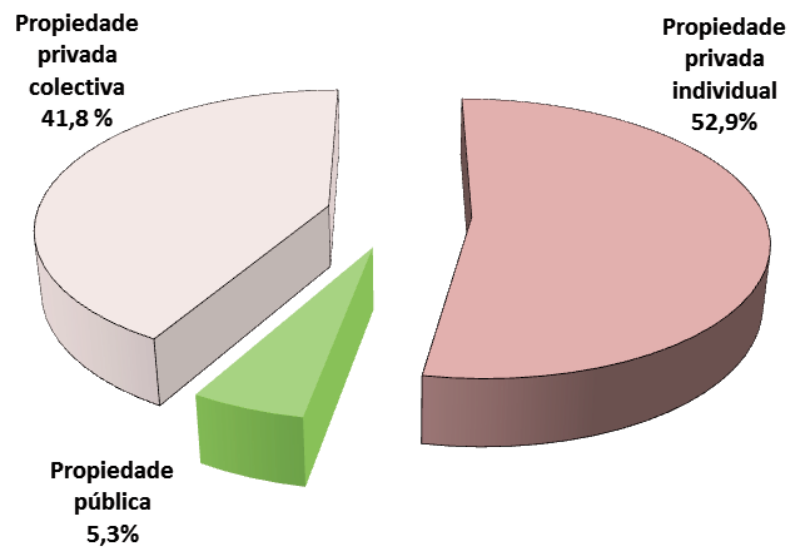

Figura 3.- Distribución da titularidade da propiedade nos ENP galegos

Os PORN concíbense como instrumentos flexibles que, fuxindo de pretensións inviables, permitisen un tratamento prioritario e integral en determinadas zonas para a conservación e recuperación dos recursos, espazos naturais e especies a protexer. Ademais, estes plans adquirían a condición de instrumentos de planificación territorial, extendendo o seu ámbito de aplicación ao territorio situado fora das áreas consideradas como espazos naturais protexidos. Para elo, eran constituidos como un límite para calquera outro tipo de instrumento de ordenación territorial ou física, prevalecendo sobre os existentes, ata o punto de que estes non poderían alterar ou modificar as determinacións establecidas nos PORN, debendo adaptarse a estes en caso de contradición. Esta consideración tomábase como indispensable para atallar o grave deterioro que sobre a natureza producira a acción do ser humano.

Ademais da condición de instrumento territorial, os PORN quedaban constituidos pola Lei 4/1989 como os documentos de referencia no tocante á planificación dos recursos naturais, establecendo que a declaración de Parques e Reservas esixiría a previa elaboración e aprobación do correspondente PORN por parte dos organismos autonómicos competentes.

En segundo lugar, disponse a execución dos PRUX, como instrumentos para fixar as normas xerais de uso e xestión dos Parques, de xeito que os órganos de xestión destes espazos eran os encargados de elaborar estes Plans. Do mesmo xeito que os PORN, a Lei establecía que os PRUX prevalecerían sobre o planeamento urbanístico, dispoñendo que cando as súas determinacións fosen incompatibles coa normativa urbanística en vigor, este debería ser revisada de oficio polos órganos competentes.

Ao abeiro do ronsel de declaracións de ENRPX que xurdirán en Galicia tras a promulgación do Decreto 82/1989, xurdirán os primeiros instrumentos de planificación dos recursos naturais ao abeiro da Lei 4/1989, con motivo das primeiras declaracións de Parques Naturais baixo as competencias da Comunidade Autónoma de Galicia, os cales emanarán dos ENRPX declarados previamente. Deste xeito, aprobaranse en 1992 e 1993 dous novos Parques Naturais galegos xunto aos seus respectivos PORN: o Complexo dunar de Corrubedo e lagoas de Carregal e Vixán, declarado mediante o Decreto 139/1992, de 5 de xuño (DOG n 113, 15/06/1992), co seu PORN aprobado mediante o Decreto 148/1992 de 5 de xuño (DOG $\left.n^{\circ} 114,16 / 06 / 1992\right)$, e o Parque Natural da Baixa Limia Serra do Xurés, declarado mediante o Decreto 29/1993 de 11 de febreiro (DGO $n^{\circ} 35,22 / 02 / 1993$ ), cuxo PORN se aprobaba no Decreto 32/1993 de 11 de febreiro (DOG n 37 , 24/02/1993).

\section{Espazos Naturais Protexidos}

\begin{tabular}{|c|c|c|c|c|}
\hline & $\begin{array}{l}\text { Superficie } \\
\text { total (ha) }\end{array}$ & $\begin{array}{c}\text { Superficie } \\
\text { mariña (ha) }\end{array}$ & $\begin{array}{l}\text { Superficie } \\
\text { terrestre (ha) }\end{array}$ & $\begin{array}{l}\text { Porcentaxe } \\
\text { continental }\end{array}$ \\
\hline \multicolumn{5}{|c|}{ ENP da Rede Galega de Espazos Protexidos } \\
\hline Parque Nacional & $8.492,4$ ha & $7.327,3$ ha & $1.165,1 \mathrm{ha}$ & $<0,1 \%$ \\
\hline Parque Natural & $49.548,5$ ha & 52,5 ha & $49.496,5$ ha & $1,7 \%$ \\
\hline ZEPVN & $390.407,9$ ha & $34.990,3$ ha & $355.417,6$ ha & $12,0 \%$ \\
\hline Monumento Natural & $1.396,4$ ha & 24,9 ha & $1.371,5$ ha & $<0,1 \%$ \\
\hline HumidalProtexido & $7.697,5$ ha & $3.264,5$ ha & $4.433,0$ ha & $0,1 \%$ \\
\hline PaisaxeProtexida & 917,7 ha & 0,0 ha & 917,7 ha & $<0,1 \%$ \\
\hline \multicolumn{5}{|c|}{ ENP fora da Rede Galega de Espazos Protexidos } \\
\hline ENIL & 789,9 ha & 2,5 ha & 787,4 ha & $<0,1 \%$ \\
\hline EPIN & 9,7 ha & 0,0 ha & 9,7 ha & $<0,1 \%$ \\
\hline Total ENP & $399.216,0$ ha & $38.646,6 \mathrm{ha}$ & $360.569,4$ ha & $12,2 \%$ \\
\hline
\end{tabular}

Táboa 1.- Superficies continentais e mariñas das diferentes categorías de Espazos Naturais Protexidos declarados en Galicia na actualidade 
Tres anos despois do anterior, aprobábase un novo PORN para o territorio galego, o relativo ao espazo das Fragas do Eume, mediante o Decreto 211/1996 de 2 de maio (DOG $n^{\circ}$ $110,05 / 06 / 1996)$, tras os trámites de audiencia aos interesados, información pública e consulta dos intereses afectados. Este plan incluía a necesidade de sometemento ao procedemento de avaliación de impacto ambiental de todas aquelas actuacións que produciran unha alteración física ou unha perda dos valores naturais, culturais, científicos ou educativos no ámbito territorial do Plan. Ao ano seguinte da aprobación do PORN, declarábase o Parque Natural das Fragas do Eume mediante o Decreto 218/1997 de 30 de xullo (DOG n 153, 11/08/1997), cuxo ámbito territorial era o que figuraba no Decreto 211/1996, aínda que se contemplaba que o goberno autonómico podería incorporar ao parque outros terreos estremeiros que reunisen as características para tal fin, no caso de terreos de propiedade pública, de propiedade privada aportados voluntariamente polos titulares, así como aqueles que se considerasen apropiados para mellorar e garantir a conservación do espazo.

Previamente á declaración do Parque Natural das Fragas do Eume, aprobábase a declaración doutro Parque Natural, de 5.722 ha, situado no macizo montañoso central ourensán do Invernadeiro, a través do Decreto 155/1997 de 5 de xuño (DOG $\left.n^{\circ} 123,27 / 06 / 1997\right)$. As principais novidades que constitúen a declaración deste Parque Natural, con respecto aos declarados previamente (así como cos que se declararán con posterioridade), é o seu réxime de propiedade, no que as 5.722 ha declaradas están conformadas por unha soa parcela, de propiedade da Xunta de Galicia, así como o feito da inexistencia de núcleos humanos habitados no seu interior. Estes aspectos provocan que tanto a xestión, como a súa planificación, sexan desenvolvidas baixo diferentes condicionantes que no resto de parques galegos. Non obstante a aprobación do correspondente PORN non ocorrerá ata 2 anos despois, mediante o Decreto 166/1999 de 27 de maio (DOG n 106, 04/06/1999)

O Parque Natural da Baixa Limia - Serra do Xurés será o primeiro Espazo Natural Protexido de Galicia que continúe co marco establecido na Lei 4/1989, aprobando o seu Plan Reitor de Uso e Xestión (PRUX), o primeiro de Galicia, mediante o Decreto 155/1998, de 28 de maio (DOG n 107, 05/06/1998).

Con todo, non soamente se aprobaban os primeiros instrumentos de planificación dos recursos naturais dos novos 4 parques naturais declarados ao abeiro da Lei 4/1989, senón que tamén se dispoñía a elaboración dos devanditos instrumentos para os parques naturais declarados con antelación. Deste xeito, mediante o Decreto $156 / 1998$ de 28 de maio (DOG $n^{\circ} 107,05 / 06 / 1998$ ) aprobábase o PORN do Parque Natural das Illas Cíes, para adecuar a xestión do espazo e das especies aos principios inspiradores da Lei 4/1989. Non obstante, quedará derrogado un ano despois da súa publicación, posto que a Xunta de Galicia, facéndose eco das diferentes propostas xurdidas dende diferentes ámbitos, así como habida conta da excepcionalidade dos valores albergados no espazo, daba un paso adiante no ano 1999 cara a declaración como
Parque Nacional das Illas Cíes, xunto aos arquipélagos de Ons e Sálvora, a través da aprobación do Plan de Ordenación dos Recursos Naturais das Illas Atlánticas, mediante o Decreto 274/1999 de 21 de outubro (DOG $\mathrm{n}^{\circ}$ $209,28 / 10 / 1999)$, tras os respectivos trámites de audiencia aos interesados, información pública e consulta dos intereses sociais.

A declaración deste territorio como futuro espacio protexido tiña por obxecto conservar a integridade dos ecosistemas incluídos nos arquipélagos, que constitúen unha representación significativa dos sistemas naturais e seminaturais asociados á vexetación de acantilados e os procesos xeodinámicos mariños (sistemas dunares), así como dos elementos físicos e biolóxicos que os caracterizan. Así mesmo, tiña como obxectivo contribuír á protección, recuperación, fomento e difusión dos valores culturais e antropolóxicos que conforman a historia deste territorio, permitindo o coñecemento e desfrute dos principais valores e asegurando, sempre de xeito compatible coa súa conservación, tanto a actividade investigadora e educativa como o simple acceso dos visitantes. Finalmente, a declaración deste espacio protexido promovería o desenvolvemento social, económico e cultural sostible para as persoas e comunidades asociadas ao seu ámbito territorial e área de influencia, garantindo a súa participación en todo o proceso. Deste xeito, os beneficios serían múltiples, posto que se achegaría ao patrimonio nacional, europeo e mundial unha mostra representativa dos ecosistemas insulares de acantilados e de dinámica dunar dos arquipélagos galegos das Cíes, Ons e Sálvora e o seu legado natural e cultural, co que se podería participar nos programas nacionais e internacionais de conservación da biodiversidade.

\section{A planificación baixo a Lei 9/2001}

Os aspectos relativos á planificación establecidos pola Lei 4/1989 serán herdados e desenvolvidos para o ámbito galego mediante a Lei 9/2001. Deste xeito, esta Lei establece 3 tipos de instrumentos de planificación, ordeados por orden de prevalencia: os Plans de Ordenación dos Recursos Naturais (PORN) e os Plans Reitores de Uso e Xestión (PRUX), adoptados directamente da Lei 4/1989, e como innovación introduce os Plans de Conservación (PC), nova figura de planificación ao abeiro da lexislación autonómica galega.

Do mesmo xeito que o establecido na Lei 4/1989, a Lei 9/2001 dispón que nas reservas naturais e nos parques requirirase con carácter previo a aprobación do correspondente Plan de Ordenación dos Recursos Naturais (PORN), mentres que a súa xestión levarase a cabo mediante Plans Reitores de Uso e Xestión (PRUX). Non obstante, a principal novidade neste aspecto ven relacionada co novo instrumento de planificación introducido pola Lei 9/2001, posto que se establece que nas demais categorías de Espazos Naturais Protexidos (Monumentos Naturais, Paisaxes Protexidas, Humidais Protexidos, Zonas de Especial Protección dos Valores Naturais, Espazos Naturais de Interese Local e Espazos 
Privados de Interese Natural) sexa necesaria cando menos a aprobación dun Plan de Conservación, novidade tanto para os espazos contemplados previamente na lexislación estatal (Monumentos Naturais e Paisaxes Protexidas) como para as restantes introducidas ao abeiro da lexislación autonómica.

Os Plans de Conservación serán vinculantes, tanto para as administracións públicas coma para os particulares, e do mesmo xeito que os outros dous tipos de instrumentos de planificación establecidos pola Lei 9/2001, prevalecerán sobre o planeamento urbanístico, establecendo ademais que a súa aprobación levará aparellada a revisión dos plans territoriais ou sectoriais incompatibles con eles. A formulación destes plans, ao igual que os PORN e PRUX, recaerá sobre o organismo competente en materia de conservación da natureza, con excepción dos correspondentes aos espazos excluídos da Rede Galega de Espazos Protexidos (Espazos Naturais de Interese Local ENIL e Espazos Privados de Interese Natural EPIN), para os que segundo o Decreto $124 / 2005$ os organismos, institucións ou propietarios dos que proceda a iniciativa para a declaración destas dúas categorías de espazos naturais protexidos deberán comprometerse á súa elaboración. Con todo, a aprobación destes plans deberá someterse a información pública e audiencia dos interesados que comparecesen no expediente. Trala realización dos trámites referidos elevaráselle ao Consello da Xunta de Galicia para a súa aprobación mediante decreto.

A pesares do desenvolvemento no ámbito normativo galego do marco de planificación dos recursos naturais coa promulgación da Lei 9/2001, na que se contemplaba incluso a creación dunha figura propia (o Plan de Conservación), tras a súa aprobación o ritmo de aprobación de instrumentos de planificación dos recursos naturais sufrirá un forte descenso, sobre todo en comparación co período transcorrido entre os anos 1989 e 2001.

O primeiro PORN tras a Lei 9/2001, será o do restante Parque Natural aprobado con anterioridade á Lei 4/1989, e que por tanto carecía do correspondente documento de planificación: Monte Aloia. O seu PORN será aprobado mediante o Decreto $274 / 2001$ de 27 de setembro (DOG $n^{\circ}$ $205,23 / 10 / 2001)$, un mes despois da promulgación da Lei 9/2001, incorporando ao seu articulado as disposicións da mesma. O procedemento de elaboración deste PORN incluíu trámites de información pública e audiencia aos interesados, e consulta dos intereses sociais e informe favorable por unanimidade da Xunta Reitora.

Coa aprobación do PORN do Parque Natural do Monte Aloia, o $100 \%$ da superficie incluida nos parques naturais de Galicia naquel momento estaba suxeita, cando menos, á planificación establecida polo seu correspondente instrumento, ao abeiro da Lei 4/1989 e da Lei 9/2001. No sucesivo, a declaración dos novos parques levará asociado o seu correspondente instrumento de planificación, aínda que esto soamente ocorrerá ao ano seguinte, coa aprobación dun novo Parque Natural (Serra da Enciña da Lastra) e do único Parque Nacional galego (Illas Atlánticas de Galicia).
A escaseza de territorios desenvolvidos sobre materiais calcarios en Galicia provocaba que no ano 2002 se plantexase a necesidade de ordenar as actividades humanas no macizo ourensán da Serra da Enciña da Lastra, mediante o seu correspondente PORN, aprobado mediante o Decreto $77 / 2002$ de 28 de febreiro (DOG n ${ }^{\circ} 55$, $18 / 03 / 2002)$, tras incluír, entre outros, os trámites de información pública e audiencia aos interesados. A declaración do correspondente Parque Natural será realizada mediante o Decreto 157/2002 de 4 de abril (DOG $\left.n^{\circ} 85,03 / 05 / 2002\right)$. Cabe salientar que este será o primeiro PORN que inclúa un diagnóstico dos valores albergados polo espazo segundo os criterios da Rede Natura 2000, a pesares de que xa transcurrían 10 anos dende a promulgación da DC 92/43/CEE, e algo menos dende a súa transposición ao dereito español a través do RD 1997/1995. Os PORN posteriores á normativa comunitaria incluían a súa referencia, pero dende un punto secundario, non incluíndo nas súas medidas de xestión as necesidade de conservación dos tipos de hábitats e especies de interese comunitario.

Por outra banda, a pesares de que no Decreto 274/1999 se ampliaba o ámbito de ordenación aos arquipélagos de Ons e Sálvora con respecto ao ámbito establecido no PORN das Illas Cíes (Decreto 156/1998), existiron diversas iniciativas de agrupacións cidadás, de grupos ecoloxistas, entidades municipais e doutras administracións que, ao longo dos anos seguintes, foran demandando o establecemento dalgún tipo de figura de protección sobre o arquipélago de Cortegada, situado na Ría de Arousa, por consideraren que alberga valores naturais, culturais e etnográficos de interese. Tendo en conta que os valores do mesmo se consideraron complementarios cos das denominadas Illas Atlánticas, redactábase o Plan de Ordenación dos Recursos Naturais do arquipélago de Cortegada, que era aprobado mediante o Decreto 88/2002 de 7 de marzo (DOG n 62, 01/04/2002), tras incluír os correspondentes trámites de información pública e audiencia aos interesados. A aprobación deste PORN, xunto ao aprobado para os arquipélagos de Cíes, Ons e Sálvora (Decreto 274/1999), permitía a declaración definitiva do Parque Nacional Marítimo Terrestre das Illas Atlánticas de Galicia, mediante a Lei 15/2002 de 1 de xullo (BOE n 157, 02/07/2002), de carácter estatal.

Non obstante, a pesares do descenso no ritmo de aprobación de documentos de planificación dos recursos naturais evidenciado tras a entrada en vigor da Lei 9/2001, esto non era indicativo de que non se iniciase a elaboración de novos documentos. Algúns dos espazos propostos para a Rede Natura 2000 eran obxecto da promoción do seu correspondente instrumento de planificación, tramitados baixo a figura de Plan de Ordenación dos Recursos Naturais, iniciándose os correspondentes procedementos de elaboración: comezaban este trámite Ortigueira-Mera e Os Ancares - O Courel (Orde de 14 de febrero de 2001, DOG n 37, 21/02/2001), seguidos por Pena Trevinca (Orde de 19 de abril de 2002, DOG n 83, 30/04/2002), Complexo Ons - O Grove (Orde de 17 de outubro de 2002, DOG $n^{\circ}$ 206, 24/10/2002) e Parga-Ladra-Támoga (Orde do 18 de xuño de 2003, DOG n 125, 30/06/2003). Sen embargo, o 
trámite dos mesmos nunca será finalizado, e soamente os dous exemplos lucenses contarán con cadanseu PORN (Rigueiro Rodríguez et al. 2005, Ramil Rego \& Crecente Maseda 2005), que serán sometidos ao procedemento de información pública e audiencia aos interesados (Resolucións de 22 de xullo de 2005, DOG $\mathrm{n}^{\circ}$ 145, 29/07/2005), aínda que tampouco se chegarán a aprobar definitivamente.

\section{A planificación coa Lei 42/2007}

Con motivo da aprobación da Lei 42/2007, derogábase a Lei 4/1989. Con todo, a nova ven a confirmar aos PORN e PRUX como instrumentos de planificación. Os primeiros perfílanse como o instrumento específico das comunidades autónomas para a delimitación, tipificación, integración en rede (aspecto que xa fora contemplado na Lei 9/2001, de conservación da natureza, e que agora adoptaba a lexislación estatal) e determinación da súa relación co resto do territorio, dos sistemas que integran o patrimonio e os recursos naturais dun determinado ámbito espacial. No tocante aos PRUX, a Lei 42/2007 contempla a súa redacción para os parques, cuxa aprobación lle corresponderá ao órgano competente da comunidade autónoma. Con todo, os contidos mínimos dos PRUX non se establecen na Lei $42 / 2007$, xa que no tocante aos Parques Naturais seguirase a normativa autonómica (Lei 9/2001), mentres que no que respecta aos Parques Nacionais estarase ao disposto na Lei 5/2007 (de 3 de abril, da Rede de Parques Nacionais). De xeito análogo ao establecido na Lei 4/1989, as disposicións contidas nos PORN e PRUX constituirán un límite de calquera outro instrumento de ordenación territorial ou física, prevalecendo sobre os xa existentes.

O primeiro PORN aprobado ao abeiro da Lei 42/2007 será o elaborado con motivo da ampliación do Parque Natural da Baixa Limia - Serra do Xurés (Ramil Rego 2008), e que será aprobado mediante o Decreto 64/2009, de 19 de febreiro (DOG n 61, 30/03/2009). Durante o intervalo de 16 anos transcurridos dende o primeiro PORN (Decreto 32/1993), o marco normativo estatal (RD 1997/1995, Lei 42/2007) e autonómico (Lei 9/2001) foran profundamente modificados, ademais de que o ámbito territorial do parque fora incluído na Rede Natura 2000 como LIC e ZEPA, declarándose ambos espazos ao abeiro da Lei 9/2001 baixo a figura de ZEPVN (Decreto 72/2004 de 2 de abril, DOG $n^{\circ} 69$, 12/04/2004). Coa promulgación do Decreto 64/2009, o marco de planificación do espazo incorporará agora os principios de ordenación e xestión da Lei 9/2001 e da Lei 42/2007, así como os obxectivos de conservación da Rede Natura 2000. A aprobación da ampliación do Parque Natural será declarada mediante o Decreto 401/2009, de 22 de outubro (DOG n² 212, 29/10/2009).

Paralelamente á aprobación do PORN relativo á ampliación do Parque Natural da Baixa Limia - Serra do Xurés, desenvolvíase o Plan Reitor de Uso e Xestión (PRUX) do Parque Natural do Monte Aloia, aprobado mediante o Decreto 65/2009, de 19 de febreiro (DOG $n^{\circ}$ 62, $31 / 03 / 2009)$. Este plan, habida conta das novidades xurdidas dende a aprobación do correspondente PORN no ano 2001, inclúe novos criterios e directrices introducidos a través das actualizacións e promulgacións posteriores, como por exemplo os principios da Lei 42/2007 ou os criterios da Rede Natura 2000, posto que o Monte Aloia fora incluído definitivamente nesta última e declarado como ZEPVN mediante o Decreto 72/2004.

Deste xeito, tras a promulgación da Lei 42/2007, as aportacións ao panorama da planificación dos parques naturais en Galicia se restrinxiron a unha lixeira actualización que da lugar na actualidade a unha situación de heteroxeneidade (Figura 4): nalgún parque xa se dispuxo dun segundo PORN (Baixa Limia - Serra do Xurés), noutros casos o documento leva vixente máis de 20 anos (Corrubedo), soamente dous parques dispoñen de PRUX aprobado (Baixa Limia - Serra do Xurés, Monte Aloia), mentres os restantes carecen do mesmo, e nalgúns casos tras máis de 15 anos tras a súa declaración (Corrubedo, Fragas do Eume, Invernadeiro).

Con todo, durante este período os episodios máis salientables no tocante á planificación dos Espazos Naturais Protexidos en Galicia producíanse de xeito moi recente, debido ao prolongado retraso que acumulaba algún proceso que se atopaba en marcha, ou noutros casos debido á inexistencia dun documento de ordenación e planificación dos recursos naturais para a conservación dos valores a protexer en espazos de elevada fraxilidade ou vulnerabilidade.

O primeiro fito será a aprobación definitiva do instrumento de planificación para a figura de espazos naturais protexidos que maior ámbito territorial (un 98\%) abranguen en Galicia (Táboa 1): as Zonas de Especial Protección dos Valores Naturais (ZEPVN). Baixo esta figura foron incluídos os espazos Rede Natura 2000 de Galicia (Decreto 72/2004, Decreto 131/2008, Decreto 411/2009), delimitados nun 95\% da súa superficie sobre terreos de titularidade privada (Figura 3), e para os que deberían elaborarse os apropiados plans de conservación e xestión ao abeiro da normativa comunitaria que a regula (DC 92/43/CEE). Tras sucesivos intentos por parte do organismo autonómico competente, adoptando diferentes figuras e estratexias para a elaboración do documento, finalmente optouse máis recentemente pola modalidade de Plan de Ordenación dos Recursos Naturais (PORN), como figura establecida pola Lei 42/2007 para a planificación e xestión en Rede (GarcíaBorregón 2012). En consecuencia, elaborouse o Plan Director da Rede Natura 2000 de Galicia (Ramil Rego et al. 2012), documento que incorpora os avances científicos máis salientables no tocante á identificación e valoración dos compoñentes clave da biodiversidade (Ramil Rego et al. 2005, 2008a, b).

O ámbito territorial do Plan Director abrangue os LIC (logo declarados ZEC) e ZEPA da Rede Natura 2000 de Galicia, ademais doutras figuras de Espazos Naturais Protexidos incluídos na Rede Galega de Espazos Protexidos: o Parque Nacional, os 7 Parques Naturais, os 5 Humidais Protexidos, 5 Monumentos Naturais (O Souto da Retorta, O Souto de Rozabales, A Costa de Dexo, A Praia das Catedrais, Pregamento Campodola Leixazós). Sen embargo, tras o 
seu sometemento ao procedemento de participación do público no ano 2011, e posteriormente ao de información pública e audiencia aos interesados en 2012, a tramitación deste instrumento de planificación non vería a luz ata dous anos máis tarde, con motivo da súa aprobación mediante o Decreto 37/2014, de 27 de marzo (DOG n 62, 31/03/2014). Esto provocaba que o $98 \%$ da Rede Galega de Espazos Protexidos sufrise un dilatado retraso de máis de dez anos para dispoñer dun documento de planificación aprobado, tras un prolongado ronsel de controversias e conflitos motivados pola carencia de medidas de conservación e xestión, o cal resultaba de grande relevancia tendo en conta a titularidade privada da práctica totalidade dos territorios da Rede Natura 2000 de Galicia.

De xeito máis recente, cabe salientar a aprobación dos primeiros Plans de Conservación (Táboa 2 ) relativos a Espazos Naturais Protexidos incluídos na Rede Galega de Espazos Protexidos (Figura 4): o Humidal Protexido da Lagoa e Areal de Valdoviño e o Monumento Natural da Praia das Catedrais. Non obstante, non poden ser considerados os primeiros Plans de Conservación de Espazos Naturais Protexidos en Galicia, xa que esta condición foi acadada por plans elaborados ao abeiro da iniciativa privada e municipal, como se verá en epígrafes posteriores.

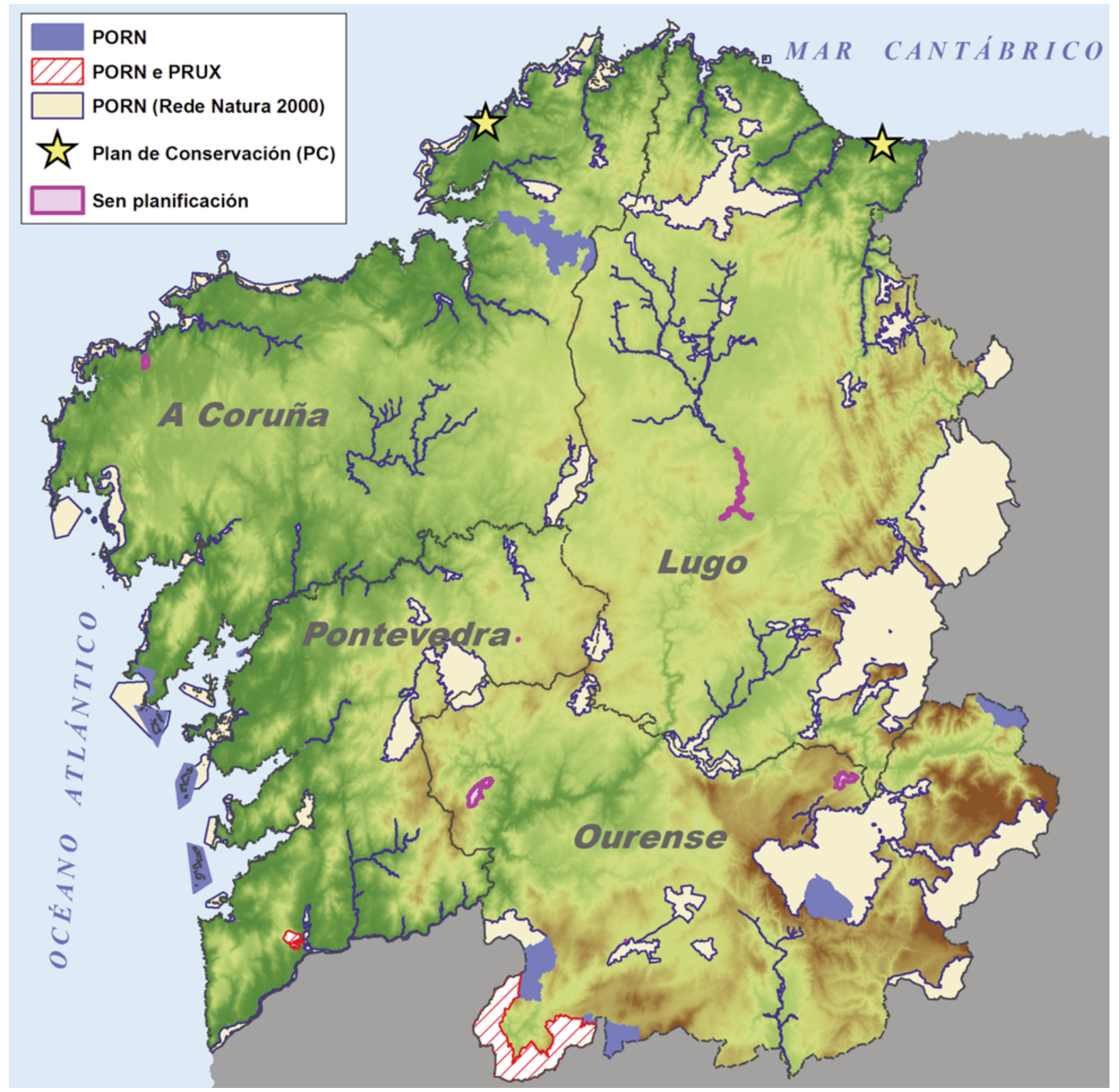

Figura 4.- Panorama de planificación dos Espazos Naturais Protexidos incluídos na Rede Galega de Espazos Protexidos 


\begin{tabular}{|c|c|c|c|c|}
\hline \multicolumn{5}{|c|}{ Instrumentos de Planificación - RGEP } \\
\hline \multicolumn{5}{|c|}{ Plans de Ordenación dos Recursos Naturais (PORN) } \\
\hline & \multicolumn{2}{|c|}{ Declaración do Espazo } & \multicolumn{2}{|c|}{ PORN } \\
\hline Espazo Natural Protexido & Norma & BOE/DOG & Norma & DOG \\
\hline $\begin{array}{ll}\text { Parque Nacional } & \text { Cies, Ons-Sálvora } \\
\text { Atlanticas } & \text { Cortegada } \\
\end{array}$ & Lei $15 / 2002$ & 02/07/2002 & $\begin{array}{l}\text { D 274/1999 } \\
\text { D 88/2002 } \\
\end{array}$ & $\begin{array}{l}28 / 10 / 1999 \\
01 / 04 / 2002 \\
\end{array}$ \\
\hline Parque Natural de Monte Aloia & RD 3160/1978 & 18/01/1979 & D 274/2001 & $23 / 10 / 2001$ \\
\hline Parque Natural de Corrubedo & D 139/1992 & 15/06/1992 & D 148/1992 & $16 / 06 / 1992$ \\
\hline Parque Natural das Fragas do Eume & D218/1997 & $11 / / 08 / 1997$ & D 211/1996 & $05 / 06 / 1996$ \\
\hline Parque Natural da Baixa Limia & D 401/2009 & $29 / 10 / 2009$ & D 64/2009 & $30 / 03 / 2009$ \\
\hline Parque Natural do Invernadeiro & D 155/1997 & $27 / 06 / 1997$ & D 166/1999 & $04 / 06 / 1999$ \\
\hline Parque Natural da Enciña da Lastra & D 157/2002 & $03 / 05 / 2002$ & D 77/2002 & $18 / 03 / 2002$ \\
\hline Rede Natura 2000 - ZEPVN & Varios & Varios & D 37/2014 & $31 / 03 / 2014$ \\
\hline \multicolumn{5}{|c|}{ Plans Reitores de Uso e Xestión (PRUX) } \\
\hline & \multicolumn{2}{|c|}{ Declaración do Espazo } & \multicolumn{2}{|c|}{ PRUX } \\
\hline Espazo Natural Protexido & Norma & DOG & Norma & DOG \\
\hline Parque Natural da Baixa Limia & D 401/2009 & $29 / 10 / 2009$ & D 155/1998 & $05 / 06 / 1998$ \\
\hline Parque Natural de Monte Aloia & RD 3160/1978 & $18 / 01 / 1979$ & D $65 / 2009$ & $31 / 03 / 2009$ \\
\hline Parque Nacional das Illas Atlánticas & Lei $15 / 2002$ & $02 / 07 / 2002$ & Participación & iblica (2011) \\
\hline Parque Natural das Fragas do Eume & D218/1997 & $11 / / 08 / 1997$ & Participación & blica (2015) \\
\hline \multicolumn{5}{|l|}{ Plans de Conservación (PC) } \\
\hline & \multicolumn{2}{|c|}{ Declaración Espazo } & \multicolumn{2}{|c|}{ PC } \\
\hline Espazo Natural Protexido & Norma & DOG & Norma & DOG \\
\hline Humidal Protexido de Valdoviño & D 110/2004 & $07 / 06 / 2004$ & D 30/2015 & $25 / 02 / 2015$ \\
\hline Monumento Natural das Catedrais & D 11/2005 & $04 / 02 / 2005$ & D 80/2015 & $12 / 06 / 2015$ \\
\hline
\end{tabular}

Táboa 2.- Instrumentos de planificación existentes nos Espazos Naturais Protexidos (ENP) incluídos na Rede Galega de Espazos Protexidos (RGEP)

O Plan de Conservación do Humidal Protexido da Lagoa e Areal de Valdoviño aprobábase mediante o Decreto 30/2015, de 5 de febreiro (DOG n 38, 25/02/2015), mentres que o Plan de Conservación do Monumento Natural da Praia das Catedrais era aprobado no Decreto 80/2015, de 11 de xuño (DOG no 110, 12/06/2015). Diferentes conflitos no tocante á conservación e xestión dos valores que motivaron a súa declaración obrigaron á elaboración urxente dos respectivos instrumentos de planificación, non sen unha década de retraso con respecto á súa declaración: o Humidal Protexido da Lagoa e Areal de Valdoviño fora declarado inicialmente polo Decreto 110/2004 (modificado polo Decreto 132/2005, e substituído polo Decreto 127/2008), mentres que o Monumento Natural da Praia das Catedrais fora declarado no Decreto 11/2005.

Con todo, durante o período transcorrido dende a aprobación da Lei 42/2007, foron xurdindo algunhas iniciativas de planificación que, como no período anterior, non prosperaron. Neste sentido, cabe citar a iniciativa para a declaración do Parque Natural dos Ancares, o que motivou a elaboración do seu correspondente PORN (Ramil Rego \& Rigueiro Rodríguez 2008). No tocante aos PRUX, xurdiron iniciativas para novas aprobacións desta tipoloxía de instrumentos de planificación (Táboa 2) no Parque Nacional das Illas Atlánticas de Galicia (Anuncio de 26 de xullo de 2011, DOG $\left.n^{\circ} 156,07 / 08 / 2011\right)$ ou no Parque Natural das Fragas do Eume (Anuncio de 8 de xaneiro de 2015, DOG $\left.n^{\circ} 17,27 / 01 / 2015\right)$. A oposición de diversos sectores á regulación e planificación dos recursos naturais dende unha perspectiva de sostibilidade, motivaron a paralización do procedemento no primeiro caso, e a ralentización nos seguintes exemplos, impedindo a disposición dos respectivos documentos aprobados mediante cadanseus Decretos. Contrasta esta situación con iniciativas máis recentes, xurdidas dende o sector privado, nas que se demanda a declaración de novos Parques Naturais, como é o caso do Monte Pindo.

A pesares do longo percorrido que seguiu a planificación dos Espazos Naturais Protexidos da Rede Galega de Espazos Protexidos, aínda na actualidade quedan espazos cuxo ámbito territorial non se inclúe nun instrumento de planificación e xestión (Figura 4) ao abeiro da Lei 9/2001 e da Lei 42/2007. Estes son os casos das 2 Paisaxes Protexidas declaradas en Galicia (Val do río Navea e Penedos de Pasarela e Traba), 3 Monumentos Naturais (A Fraga de Catasós, A Carballa da Rocha e Serra de Pena Corneira), e a ZEPVN Miño-Neira.

\section{O auxe das iniciativas locais e privadas}

Segundo o explicado en parágrafos anteriores, tras a promulgación da Lei 42/2007 diminuía significativamente en Galicia o ritmo de declaracións de espazos promovidos polos organismos competentes na materia (e incluídos por tanto na Rede Galega de Espazos Protexidos). Por contra, 
cobraron importancia (no tocante ao número de espazos designados) as declaracións de Espazos Naturais Protexidos baixo as categorías que a Lei 9/2001 non inclúe dentro da Rede Galega de Espazos Protexidos (RGEP): os Espazos Naturais de Interese Local (ENIL), e os Espazos Privados de Interese Privado (EPIN). A exclusión destes espazos da Rede Galega de Espazos Protexidos supón que a súa declaración non implicará a asignación de recursos da Comunidade Autónoma, aínda que poderán ter preferencia na obtención de axudas para a súa conservación e xestión. A regulación específica dos ENIL e EPIN establécese no Decreto 124/2005, de 6 de maio (DOG n 97, 23/05/2005), detallando moito máis polo miúdo o procedemento, declaración, efectos, xestión, instrumentos de planificación, etc.

Os Espazos Naturais de Interese Local (ENIL) son espazos promovidos a petición do concello e logo de informe do organismo autonómico competente en materia de urbanismo e ordenación do territorio, poderán ser declarados polo organismo autonómico competente en materia de conservación da natureza. Nesta categoría incluiranse espazos que polas súas singularidades sexan merecedores dalgún tipo de protección dos seus valores naturais. A responsabilidade e competencia na xestión destes espazos será municipal. Con todo, estes espazos poden incluír igualmente terreos de titularidade privada, tras o correspondente acordo co promotor da declaración.
No tocante aos Espazos Privados de Interese Natural (EPIN), as institucións e os propietarios particulares dos terreos nos que existan formacións naturais, especies ou hábitats de flora e fauna silvestres dos que se considere de interese a súa protección poderanlle propoñer ao organismo autonómico competente en materia de conservación da natureza, mediante a presentación dunha memoria suficientemente motivada, a súa declaración como EPIN. A declaración supón o compromiso formal do promotor de poñer en práctica as medidas precisas para a conservación dos valores naturais que o motivaron.

\section{Promoción de declaración de espazos privados e municipais}

Dende o ano 2007 (Táboa 3) foron declarados un total de 8 ENIL (Voutureira, Puzo do Lago, Xunqueira de Alba, Illas de San Pedro, Loio-Ruxidoira, Vao-Baluarte, Río Gafos e Praia América-Panxón) e 1 EPIN (Sobreiras do Faro). En consecuencia, evidenciouse durante o período 2007-2015 un cambio na tendencia de declaración dos espazos naturais protexidos, converténdose as figuras de ENP non incluídas na RGEP as categorías baixo as que maior número de Espazos Naturais Protexidos foron declarados ata a actualidade.

\section{Instrumentos de Planificación - non RGEP}

\begin{tabular}{|c|c|c|c|c|}
\hline \multirow[b]{2}{*}{ Espazo Natural Protexido } & \multicolumn{2}{|c|}{ Declaración Espazo } & \multicolumn{2}{|c|}{ Plan de Conservación } \\
\hline & Norma & BOE/DOG & Norma & DOG \\
\hline ENIL Voutureira (San Cibrao das Viñas) & Orde $21 / 12 / 2007$ & $14 / 01 / 2008$ & \multicolumn{2}{|c|}{ En elaboración } \\
\hline EPIN Sobreiras do Faro (Oia) & Orde $18 / 02 / 2008$ & $07 / 03 / 2008$ & D 222/2010 & $12 / 01 / 2011$ \\
\hline ENIL Puzo do Lago (Maside) & Orde 30/01/2009 & $05 / 02 / 2009$ & D $12 / 2014$ & $11 / 02 / 2014$ \\
\hline ENIL Illas de San Pedro (A Coruña) & Orde 02/06/2009 & $10 / 06 / 2009$ & \multicolumn{2}{|c|}{ En elaboración } \\
\hline ENIL Xunqueira de Alba (Pontevedra) & Orde $21 / 10 / 2009$ & $27 / 10 / 2009$ & D 190/2012 & $24 / 09 / 2012$ \\
\hline ENIL Loio-Ruxidoira (Paradela) & Orde 03/10/2011 & $14 / 10 / 2011$ & D 40/2013 & $05 / 03 / 2013$ \\
\hline ENIL Vao-Baluarte (Vigo) & Orde $26 / 08 / 2013$ & $30 / 08 / 2013$ & \multicolumn{2}{|c|}{ En elaboración } \\
\hline ENIL Rio Gafos (Pontevedra) & Orde $25 / 11 / 2013$ & $11 / 12 / 2013$ & \multicolumn{2}{|c|}{ En elaboración } \\
\hline ENIL Praia América-Panxón (Nigrán) & Orde $14 / 07 / 2014$ & $17 / 07 / 2014$ & \multicolumn{2}{|c|}{ En elaboración } \\
\hline
\end{tabular}

Táboa 3.- Estado de tramitación dos Plans de Conservación dos Espazos Naturais Protexidos (ENIL e EPIN) non incluídos na Rede Galega de Espazos Protexidos (RGEP)

O cambio de paradigma en Galicia no tocante á declaración de Espazos Naturais Protexidos evidenciábase debido a dous factores principais. Por unha banda, descenderon as iniciativas de promoción e declaración de figuras de Espazos Naturais Protexidos incluídas na Rede Galega de Espazos Protexidos (Reservas, Parques, Monumentos Naturais, Paisaxes Protexidas, ZEPVN, Humidais Protexidos) dende o organismo autonómico competente na tutela dos mesmos segundo a Lei 9/2001, a diferenza dos períodos anteriores nos que se produciron importantes avances, sobre todo con motivo da posta en marcha da Rede Natura 2000, contemplando a declaración de nutridos conxuntos de espazos que abranguían importantes ámbitos territoriais. En contraste, dende o ano 2007 aumentaron e foron consolidados os espazos promovidos dende as iniciativas municipais e privadas (ENIL e EPIN), espazos non incluídos na Rede Galega de Espazos Protexidos, para os que non existe obriga de asignar recursos económicos da Comunidade Autónoma, e cuxo ámbito superficial é moito máis reducido que os doutras figuras, posto que no seu conxunto non superan as 800 ha, equivalente ao $0,03 \%$ da superficie continental galega.

Con todo, o auxe destas figuras constitúe unha iniciativa positiva na configuración dos Espazos Naturais Protexidos galegos. A posta en marcha de espazos xurdidos dende os ámbitos locais ou privados, permiten que tanto as comunidades rurais como os propietarios particulares poidan xestionar e protexer os seus espazos máis cercanos, como maiores interesados na súa conservación. 
Ademais, implican á poboación no proceso de xestión e planificación dos valores naturais e culturais, o cal redunda nunha maior valoración do territorio e unha maior concienciación con respecto á conservación da natureza. Tampouco debe esquecerse que o desenvolvemento deste tipo de proxectos contribúen á mellora da visibilidade dos espazos de interese municipal e privado, permitindo a posta en marcha de iniciativas sostibles asociadas á declaración do espazo natural, que propicien un desenvolvemento rural, social e cultural sostibles.

\section{A iniciativa municipal e privada na planificación}

O cambio na tendencia no tocante á declaración das diferentes figuras de espazos naturais protexidos, evidenciaba tamén un cambio de paradigma no marco da planificación dos recursos naturais a partires do ano 2007. Deste xeito, tras a aprobación da Lei 42/2007 se freaba a promoción de instrumentos de planificación dos recursos naturais de figuras de espazos naturais protexidos incluídas na Rede Galega de Espazos Protexidos, para dar paso a unha etapa na que se producirá un espectacular aumento no tocante aos plans (Figura 5) relativos aos novos espazos promovidos por entidades locais ou privadas (ENIL e EPIN).

Deste xeito, o primeiro Plan de Conservación galego será o relativo ao EPIN Sobreiras do Faro (Oia), aprobado mediante o Decreto $222 / 2010$ de 23 de decembro (DOG $n^{\circ}$ 7, 12/01/2011). Mediante a Orde do 18 de febreiro de 2008 (DOG n 48, do 7 de marzo), declarouse de forma provisoria o EPIN Sobreiras do Faro, de 9,72 ha, localizado no concello de Oia, e promovido pola Comunidade de Montes Veciñais en Man Común de Viladesuso. Esta entidade, ao abeiro do Decreto 124/2005, presentaba o Plan de Conservación do espazo o 2 de marzo de 2010 ante o organismo autonómico competente, o que facía ante a Consellería do Medio Rural. O Plan de Conservación establece o réxime de uso e as actividades permisibles, así como as limitacións que se consideren necesarias para a conservación do espazo.

Durante a súa tramitación, o Plan de Conservación do EPIN Sobreiras do Faro foi sometido ao ditame favorable da asemblea de comuneiros, co voto favorable de todos os asistentes, e solicitáronse os informes do Servizo de Conservación da Natureza en Pontevedra e da Dirección Xeral de Montes. Así mesmo, someteuse a información pública e audiencia dos interesados. Cabe salientar os retos e dificultades na xestión deste espazo, posto que nunha superficie tan reducida conta no seu interior ata un total de sete enclaves pertencentes a outros propietarios distintos do propoñente, que suman un total de 2,94 ha, de xeito que esta superficie encravada exclúese do ámbito da planificación. Polo tanto, a superficie suxeita ás directrices xerais de xestión e conservación do plan de conservación ascende a un total de 6,78 ha.

O segundo Plan de Conservación galego, será o correspondente ao ENIL Xunqueira de Alba, aprobándose mediante o Decreto 190/2012, de 13 de setembro (DOG n ${ }^{\circ}$ 182, 24/09/2012). O ENIL Xunqueira de Alba era aprobado de forma provisoria mediante a Orde do 21 de outubro de
2009 (DOG no 210, 27/10/2009), promovido polo Concello de Pontevedra, para a conservación dun dos escasos humidais existentes dentro do territorio municipal, ante as presións que ameazan o mantemento do seu estado de conservación. Comprende o ENIL unha superficie de 67 ha, na que se inclúen terreos clasificados como dominio público marítimo-terrestre, así como propiedades dos MVMC de Campañó e Lérez. A declaración como ENIL non implica a cesión do dominio público nin a cesión das facultades demaniais da Administración do Estado. Tampouco supón prexuízo dos aproveitamentos comunais en favor da comunidade de Campañó, nin dos aproveitamentos en favor da comunidade da parroquia de Lérez.

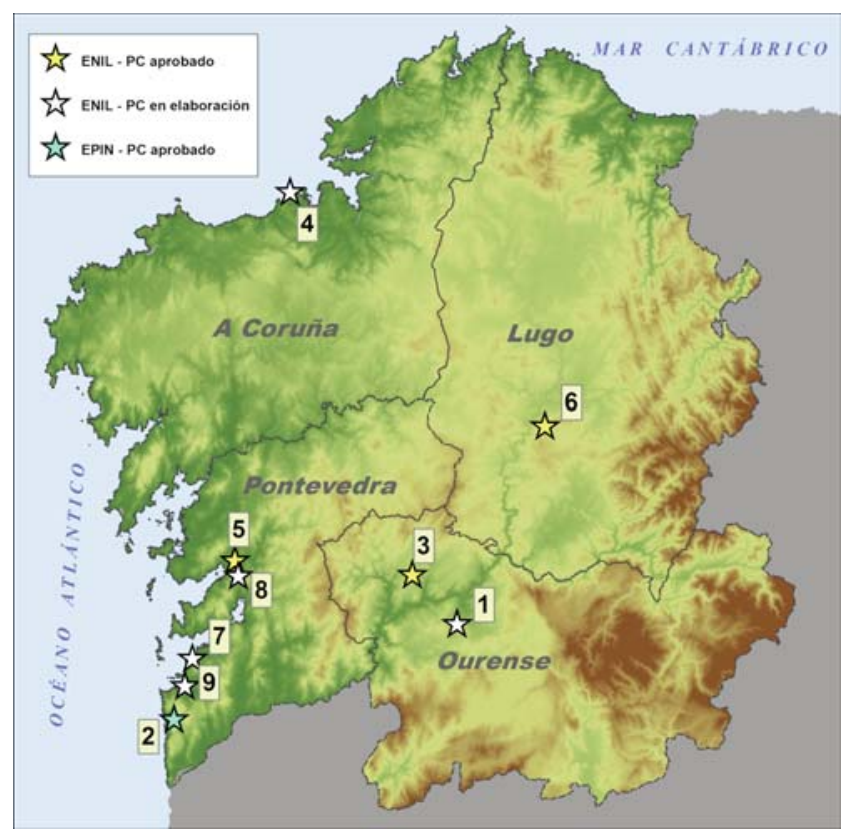

Figura 5.- Estado da planificación dos Espazos Naturais Protexidos non incluídos na Rede Galega de Espazos Protexidos: Espazos Naturais de Interese Local (ENIL) e Espazos Privados de Interese Natural (EPIN). (1: ENIL Voutureira (San Cibrao das Viñas), 2: EPIN Sobreiras do Faro (Oia), 3: ENIL Puzo do Lago (Maside), 4: ENIL Illas de San Pedro (A Coruña), 5: ENIL Xunqueira de Alba (Pontevedra), 6: ENIL Loio-Ruxidoira (Paradela), 7 ENIL Vao-Baluarte (Vigo), ENIL Río Gafos (Pontevedra), ENIL Praia América-Panxón (Nigrán))

Na tramitación do Plan de Conservación de Xunqueira de Alba, o documento foi sometido ao ditame favorable das asembleas de comuneiros de Campañó e Lérez, aprobándose nas respectivas asembleas extraordinarias do 5 de novembro de 2010 e do 15 de xullo de 2011, cos votos favorables necesarios. Tamén foron solicitados os informes do Servizo de Conservación da Natureza en Pontevedra, da Dirección Xeral de Montes, do Servizo Provincial de Costas de Pontevedra, do Organismo Autónomo Augas de Galicia e da Secretaría Xeral de Ordenación do Territorio e Urbanismo. Así mesmo, someteuse a información pública e audiencia dos interesados mediante a Resolución do 24 de marzo de 2011 (DOG n 81, 27/04/2011). 
A aprobación do Plan de Conservación permitirá a declaración definitiva como ENIL da Xunqueira de Alba, o que será efectuado mediante a Orde de 27 de agosto de 2012 (DOG no 176, 14/09/2012). Toda a información ambiental que xustifica a declaración do ENIL Xunqueira de Alba, quedaba á disposición de calquera interesado no Concello de Pontevedra, promotor e xestor do espazo.

Ao ano seguinte, un novo Plan de Conservación viña a unirse ao panorama de planificación galego, o correspondente ao ENIL Loio-Ruxidoira, aprobado mediante o Decreto 40/2013, do 21 de febreiro (DOG no 45, 05/03/2013). O ENIL Loio-Ruxidoira fora declarado de xeito provisorio mediante a Orde de 3 de outubro de 2011 (DOG $\left.n^{\circ} 197,14 / 10 / 2011\right)$, a petición do Concello de Paradela (Lugo), comprendendo unha superficie de 437 ha, incluíndo terreos clasificados como dominio público hidráulico. $\mathrm{Na}$ tramitación do espazo emitiron informes o Servizo de Conservación da Natureza en Lugo, a Secretaría Xeral de Ordenación do Territorio e Urbanismo, a Dirección Xeral de Montes, a Confederación Hidrográfica do Miño-Sil e notificouse o procedemento a Gas Natural-Generación Hidráulica, interesado no procedemento.

Vista a documentación presentada polo Concello de Paradela propoñendo a aprobación do plan de conservación do ENIL Loio-Ruxidoira, estableceuse un período de información pública e audiencia aos/ás interesados/as mediante Resolución do 11 de outubro de 2012 (DOG n² 208, 31/10/2012). A aprobación do PORN posibilitaba a declaración definitiva do ENIL Loio-Ruxidoira, que sería efectuada mediante a Orde de 13 de febreiro de 2013 (DOG n 38, 22/02/2013).

O cuarto Plan de Conservación de Galicia é o correspondente ao ENIL Puzo do Lago. Promovido polo Concello de Maside (Ourense), a súa declaración provisoria realizábase mediante a Orde de 30 de xaneiro de 2009 (DOG $n^{\circ}$ 25, 05/02/2009). O espazo abranguía unha superficie de 30,6 ha. Na súa tramitación emitiron informes o Servizo de Conservación da Natureza de Ourense e a Secretaría Xeral de Ordenación do Territorio e Urbanismo.

Vista a documentación presentada, na que o Concello de Maside propoñía a aprobación do Plan de Conservación do espazo (presentado con data 1 de xullo de 2011), decidíase someter aos borradores da Orde de declaración definitiva do ENIL e do Decreto de aprobación do propio plan a información pública mediante a Resolución de 9 de xullo de 2013 (DOG no 146, 01/08/2013). En consecuencia, o Plan de Conservación era aprobado mediante o Decreto 12/2014, de 30 de xaneiro (DOG n ${ }^{\circ} 28,11 / 02 / 2014$ ), o que permitía á súa vez a aprobación definitiva do ENIL Puzo do Lago mediante a Orde de 23 de xaneiro de 2014 (DOG n ${ }^{\circ}$ 21, 31/01/2014).

No caso dos restantes ENIL que se atopan declarados de xeito provisorio (Voutureira, Illas de San Pedro, Río Gafos, Vao-Baluarte, Praia América-Panxón), os respectivos Plans de Conservación se atopan en fase de elaboración (Figura 5). Con todo, o período que transcorre dende a declaración ata a aprobación do instrumento de planificación nos Espazos Naturais Protexidos excluídos da Rede Galega de Espazos Protexidos (Táboa 3), que xurden dende as iniciativas locais ou privadas (ENIL e EPIN), é moi inferior ao rexistrado nos Espazos Naturais Protexidos de tutela autonómica e incluídos na Rede Galega de Espazos Protexidos (Táboa 2). A iniciativa local e privada en materia de planificación dos ENIL e EPIN amosa un dinamismo e capacidade organizativa de maior eficacia que os organismos autonómicos, a cotío superados polo groso da xestión dos Espazos Naturais Protexidos da Rede Galega de Espazos Protexidos. Neste último exemplo, períodos de máis de 10 anos son habituais, sendo incluso posible atopar espazos que non posúen o seu correspondente instrumento de planificación, nin se coñece que se atopen en redacción dos correspondentes borradores.

\section{Novas ferramentas para a implicación da iniciativa privada na conservación}

$\mathrm{Na}$ actualidade considérase necesario que as políticas de conservación e xestión de espazos protexidos contribúan a impulsar procesos de mellora na sostibilidade do desenvolvemento, promovendo a utilización ordeada dos recursos naturais, para garantir o aproveitamento sostible do patrimonio natural.

Do mesmo xeito, un principio básico neste esceario é a garantía da información e participación dos cidadáns no deseño e execución das políticas públicas, incluíndo por tanto as disposicións xerais para a conservación, xestión e planificación das áreas protexidas, en aras de acadar o mantemento ou restablecemento do estado de conservación da biodiversidade, a xeodiversidade e o patrimonio natural e cultural.

Estes aspectos son implementados na actualidade a través da lexislación básica en materia de conservación da natureza, tanto a nivel comunitario (DC 92/43/CEE, DC 2009/147/CE), estatal (Lei 42/2007) e autonómico (Lei 9/2001), así como as disposicións que as desenvolven.

O patrimonio natural e a biodiversidade desempeñan unha serie de servizos á sociedade, servizos ecosistémicos, relevantes pola súa estreita vinculación coa saúde humana, a alimentación e en definitiva o benestar da sociedade. Tamén é destacable o papel que xogan na promoción do desenvolvemento social e económico, de xeito que as actividades que contribúan á conservación nun estado de conservación favorable dos procesos naturais, os ecosistemas, os tipos de hábitats e as especies de interese para a conservación, deben ser consideradas de utilidade pública ou interese social a todos os efectos en xeral, e aos efectos expropiatorios en particular.

Dentro deste escenario, a iniciativa privada pode ser un excepcional aliado na promoción de estratexias, técnicas, actuacións e iniciativas nas que se impliquen na conservación do patrimonio natural aos diferentes axentes implicados no territorio. Ademais das propias iniciativas xurdidas por entidades locais e propietarios particulares (como os exemplos abordados dos ENIL e EPIN), na actualidade estanse a poñer en marcha diversas actuacións de custodia do territorio, mediante a intervención de entidades sen ánimo de lucro, públicas ou privadas, que 
establecen acordos voluntarios con propietarios e usuarios, para o desenvolvemento de actuacións de conservación, restauración e mellora do patrimonio natural e a biodiversidade (Basora \& Sabaté 2006, Barreira 2010, Jorge 2014).

As modalidades ou tipos de acordos poden ser moi diversos. Nalgúns casos os acordos de custodia son postos en marcha para establecer un pacto entre propietario e entidade de custodia para xestionar unha parcela ou un elemento de interese etnobiolóxico, cunha finalidade de conservación, a cambio de asesoramento. Noutros casos, realízase un arrendamento ou incluso a venda da parcela, para que a entidade de custodia a destine exclusivamente á conservación dun tipo de hábitat ou dun núcleo poboacional dunha especie de interese para a conservación. Non obstante, tamén poden ser posibles casos nos que os acordos son establecidos para que a explotación dos recursos se realice baixo preceptos de sostibilidade e racionalidade. En definitiva, diversas fórmulas para unha finalidade común: a conservación da biodiversidade, a xeodiversidade, o patrimonio natural e cultural.

A Lei 42/2007 inclúe xa previsións sobre custodia do territorio, aínda que sen desenvolver o seu ámbito normativo. Non será ata a aparición do Real Decreto $1274 / 2011$ de 16 de setembro, polo que se aproba o Plan Estratéxico do Patrimonio Natural e da Biodiversidade (BOE $n^{\circ} 236,30 / 09 / 2011$ ) en aplicación da Lei 42/2007, e no que se outorga unha maior importancia á custodia do territorio no ámbito da conservación da natureza, incluíndoa como un obxectivo primordial a desenvolver no ámbito do Plan. Para tal finalidade, faise especial referencia ao fomento e recoñecemento do papel que xogan os axentes sociais e privados na xestión directa da biodiversidade, exemplificando na xestión concertada entre entidades de custodia e institucións públicas implicadas na conservación da natureza. Faise tamén fincapé na posibilidade de establecer incentivos fiscais aos propietarios que establezan acordos con entidades de custodia, partindo da voluntariedade e unha maior eficiencia dende o punto de vista financeiro posto que existe unha maior predisposición ao seu cumprimento. Deste xeito, o Plan plantexa o desenvolvemento de 5 accións primordiais para o cumprimento do obxectivo relativo á promoción da custodia do territorio:

Creación dun rexistro de entidades de custodia, determinación de tipoloxías/condicións de entidades/acordos e de formas de xestión concertada.

Promoción de acordos de custodia en terreos de titularidade estatal.

Desenvolvemento de accións para a promoción da custodia sensu lato.

Desenvolvemento de criterios de boas prácticas, modelos de acordos de custodia, modelos de seguimento da custodia.

Fomento da Responsabilidade Social Mercantil a través de iniciativas de custodia e xestión concertada de espazos naturais.

\section{As Reservas de Biosfera como marco de sostibilidade}

Tras a posta en marcha do Programa Persoa e Biosfera (MaB) da UNESCO en 1971, creábase en 1974 o concepto de Reserva de Biosfera, consistente en "harmonizar a conservación co home". A Conferencia de Sevilla en 1995 marcará unha estratexia global de funcionamento e desenvolvemento sostible das Reservas de Biosfera (Estratexia de Sevilla e Marco Estatutario da Rede Mundial de Reservas de Biosfera), para que sexan empregadas para a conservación da diversidade biolóxica natural e cultural, como modelos de desenvolvemento sostible, e como escearios para a investigación, a observación permanente, a educación e a capacitación. Nesta Conferencia tamén se establecerá o Marco Estatutario da Rede Mundial de Reservas de Biosfera.

Nos últimos anos, os aspectos básicos do programa MaB e das Reservas de Biosfera chegaron a través do Plan de Acción da Rede Mundial de Reservas de Biosfera (RMRB), coñecido como o Plan de Acción de Madrid 2008 - 2013 (PAMO). No caso das Reservas españolas, a aplicación do mesmo materializouse mediante o Plan de Acción da Rede de Reservas de Biosfera Españolas (RRBE), coñecido como Plan de Acción de Montseny 2009 -2013.

Co paso do tempo, o concepto de Reserva de Biosfera demostrou o seu valor máis alá da súa condición de área protexida. Como tal, converteuse nunha ferramenta que sen abandonar os seus obxectivos de conservación, é aproveitada por científicos, planificadores e responsables de fórmulas políticas para xerar unha variedade de coñecemento, investigacións científicas e experiencias que vinculen a conservación da biodiversidade co desenvolvemento socioeconómico sostible para o benestar da humanidade, permitindo avaliar as metodoloxías de valoración dos servizos prestados polos ecosistemas (Ramil Rego et al. 2011). Polo tanto, a atención céntrase en desenvolver e aplicar modelos para a sostibilidade mundial, nacional e local, e para que as Reservas de Biosfera sirvan de lugares de aprendizaxe onde os decisores políticos, as comunidades científicas e de investigación, os profesionais da xestión, os colectivos implicados e os sectores produtivos traballen en conxunto para converter os principios globais de desenvolvemento sostible en prácticas locais apropiadas.

Neste escenario, a figura de Reserva de Biosfera resulta de especial interese para o desenvolvemento de iniciativas privadas de conservación e desenvolvemento sostible, posto que sirve de paraugas para a posta en marcha de proxectos demostrativos, a pequena escala, para a aplicación de boas prácticas sostibles, que conxuguen a promoción económica e social do territorio coa conservación do patrimonio natural e da biodiversidade. Neste sentido, esta figura pode ser empregada como esceario e foro de debate para o intercambio de experiencias e coñecementos entre propietarios, profesionais, xestores, técnicos, científicos, etc., fomentando o desenvolvemento de capacidades e as sinerxias entre os diferentes axentes implicados. 
Este marco conceptual plásmase na actualidade na realidade das Reservas de Biosfera en Galicia (Figura 6), contando o territorio galego conta cun total de 6 territorios declarados pola UNESCO como Reservas de Biosfera. As primeiras Reservas declaradas en Galicia foron Terras do Miño (declarada no ano 2002 e integrada por 26 concellos da provincia de Lugo); Área de Allariz (declarada no ano 2005 e formada 4 concellos de Ourense); Os Ancares Lucenses e Montes de Navia, Cervantes e Becerreá (declarada no ano 2006 e conformada por 3 concellos da provincia de Lugo); e Río Eo, Oscos e Terras de Burón (declarada no ano 2007, reserva interautonómica, con 7 concellos na provincia de Lugo). Sumaríanse no ano 2009 a Reserva Transfronteiriza Gerês - Xurés (que conta con 6 concellos da província de Ourense), e no ano 2013 a Reserva das Mariñas Coruñesas e Terras do Mandeo (que inclúe 17 concellos do Noroeste da provincia da Coruña).

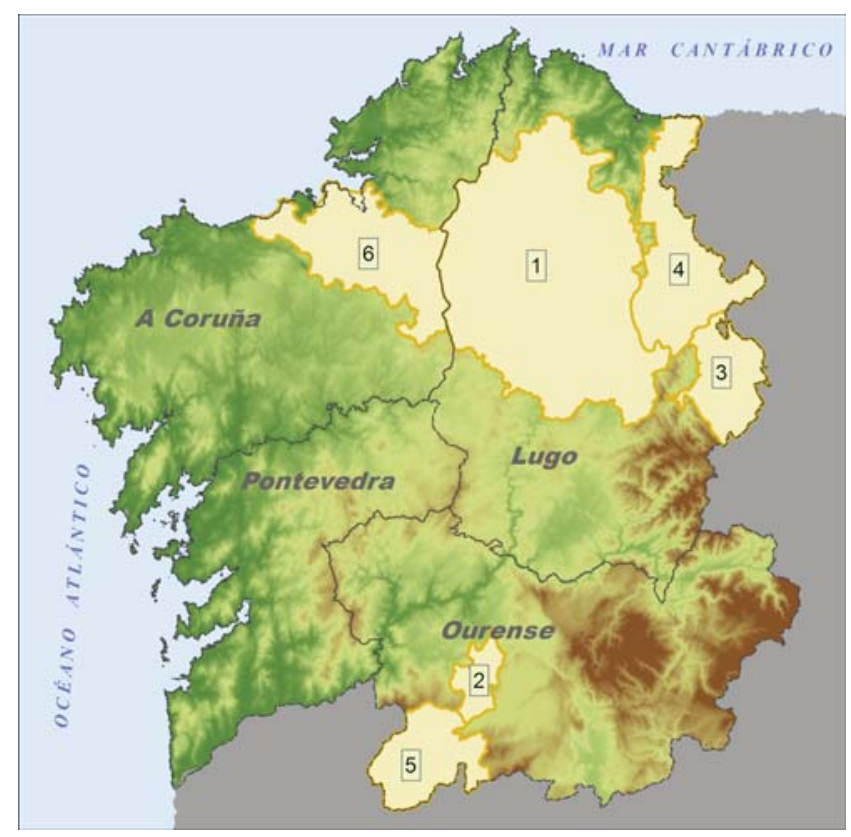

Figura 6.- Reservas de Biosfera designadas en Galicia. (1: Terras do Miño, 2: Área de Allariz, 3: Os Ancares Lucenses, 4: Río Eo, Oscos e Terras de Burón, 5: Gerês-Xurés, 6: Mariñas Coruñesas e Terras do Mandeo)

As primeiras Reservas declaradas en Galicia (Táboa 4) foron xurdindo dende a promoción por parte de organismos públicos, tanto locais (Área de Allariz), provinciais (Terras do Miño, Os Ancares Lucenses) ou autonómicos (Río Eo-
Oscos-Burón, Gerês-Xurés). A declaración das mesmas permitiu a posta en marcha dun elenco de experiencias e proxectos para a conservación, desenvolvemento sostible, difusión e promoción dos valores albergados, que serviron de guía e modelo ao resto do territorio.

Por contra, a última das Reservas (Mariñas Coruñesas e Terras do Mandeo) xurdidas ata o momento, foi xestada dende a propia poboación da Reserva, a través da Asociación de Desenvolvemento Rural (ADR) MariñasBetanzos, entidade sen ánimo de lucro na que se integran os 17 concellos que forman a Reserva, contando con máis de 125 entidades asociadas. Esta ADR desenvolveu un exhaustivo procedemento de traballo durante tres anos, no que se destacaron os aspectos que fortalecen ao territorio en canto a desenvolvemento sostible humano e económico, a forte aposta pola investigación e formación aplicada, así como a enorme cantidade de experiencias e proxectos con carácter demostrativo que se desenvolven (Blanco et al. 2011). O longo proceso desenvolvido na formulación da candidatura serviu para potenciar a participación dos distintos axentes locais, a través do desenvolvemento de xornadas de difusión, reunións cos diferentes axentes e partes implicadas, intercambios de experiencias con outras Reservas de Biosfera, actos de difusión ao público e a través da web e redes sociais, asistencias técnicas para a dinamización da candidatura, difusión aos medios, así como reunións dos órganos da propia Asociación, incluíndo a constitución dunha Comisión de seguimento da propia candidatura.

\section{Conclusións}

O panorama de declaracións de espazos protexidos foi mudando co tempo, con respecto á propiedade incluída nos mesmos. Tanto durante a etapa de xestión por parte do Estado Español (1916-1980), como nos comezos da política autonómica en materia de conservación da natureza (19801995), os espazos se compoñían maioritariamente por predios públicos ou tutelados pola Administración.

O espectacular incremento da superficie protexida en Galicia con motivo da posta en marcha da Rede Natura 2000 (1995-2001), a través da súa consideración inicial como Espazos Naturais en Réxime de Protección Xeral (ENRPX), e logo sendo declarados como Zonas de Especial Protección dos Valores Naturais (ZEPVN), realizaríase na súa maior parte sobre terreos forestais de titularidade privada, tanto colectiva como individual, representando o 98\% da Rede Galega de Espazos Protexidos. Con todo, a

\section{Reservas de Biosfera}

\begin{tabular}{llrl}
\hline \hline Espazo & Provincia & Superficie & Ano \\
\hline \hline Terras do Miño & Lugo & 363.669 ha & 2002 \\
\hline Área de Allariz & Ourense & 21.482 ha & 2005 \\
\hline Os Ancares Lucenses & Lugo & 53.664 ha & 2006 \\
\hline RioEo, Oscos e Terras de Burón & Lugo & 108.007 ha & 2007 \\
\hline Gerês-Xurés & Ourense & 62.777 ha & 2009 \\
\hline Mariñas Coruñesas e Terras do Mandeo & A Coruña & 116.724 ha & 2013 \\
\hline
\end{tabular}

Táboa 4.- Reservas de Biosfera e superficies designadas en Galicia 
tramitación dos correspondentes instrumentos de planificación foi desenvolvida de xeito heteroxéneo, acumulando prolongados retrasos e conflitos na conservación e xestión dos compoñentes naturais, cando non foi paralizada durante o seu procedemento debido á oposición de diversos sectores contra a regulación e planificación dos recursos naturais dende unha perspectiva de sostibilidade. Paradóxicamente, na actualidade están a xurdir demandas dende o sector local e privado pola declaración de novos Espazos Naturais Protexidos que garantan a conservación dos compoñentes clave da biodiversidade galega.

Nos últimos anos verificouse un cambio de paradigma na declaración das áreas protexidas galegas, consolidándose un modelo de áreas promovidas dende os concellos (ENIL) ou por entes privados (EPIN), espazos excluídos da Rede Galega de Espazos Protexidos. As entidades promotoras destes espazos amosaron un maior grao de dinamismo e consolidación na aprobación dos correspondentes instrumentos de planificación, sobre todo en comparación coa tramitación dos plans do resto de figuras de Espazos Naturais Protexidos incluídos na Rede Galega de Espazos Protexidos.

Deste xeito, a iniciativa municipal e privada pode resultar de gran interese e efectividade na conservación do patrimonio natural, xa que contribúen como maiores interesados na promoción de proxectos e estratexias nas que se impliquen aos diferentes axentes do territorio. Neste sentido, na actualidade estanse a configurar novas ferramentas para a xestión e conservación das áreas privadas, como a custodia do territorio, así como se consolidan iniciativas privadas para a declaración de espazos que contribúan á conservación da biodiversidade e a promoción do desenvolvemento sostible, como é o caso das Reservas de Biosfera.

\section{Bibliografía}

Anglada, S. (1985). Criterios para una ley básica de protección de la naturaleza: Régimen de los espacios naturales protegidos. Revista de Derecho Urbanístico, 92: 75-99.

Areses, R. (1926). La repoblación forestal. 124 pp. Diputación Provincial de Pontevedra. Tip. de Celestino Peón Villar. Pontevedra.

Areses, R. (1931). El Monte Alhoya. En: Cao Moure, J. (Dir.): Libro de oro de la provincia de Pontevedra: 118-119. P.P.K.O. Vigo.

Areses, R. (1929). Los incendios en los montes públicos. 34 pp. Imp. E. Paredes Valdés. Pontevedra.

Areses, R. (1951). Las repoblaciones forestales en Galicia, como negocio. En: Instituto de Ingenieros Civiles de España: II Congreso Nacional de Ingeniería. Tomo IV. Agricultura, Montes e Industrias derivadas: 139-156. Instituto Nacional de Investigaciones Agronómicas. Madrid.
Areses, R. (1953). La provincia de Pontevedra y la restauración forestal de sus montes. Montes, 50: 95-107.

Barreira, A. (Coord.) (2010). Estudio jurídico sobre la custodia del territorio. Plataforma de Custodia del Territorio de la Fundación Biodiversidad, 279 pp. Instituto Internacional de Derecho y Medio Ambiente (IIDMA). Fundación Biodiversidad. Madrid.

Basora Roca, X. \& Sabaté i Rotés, X. (2006). Custodia del territorio en la práctica. Manual de introducción a una nueva estrategia participativa de conservación de la naturaleza y el paisaje. Fundació Territori i Paisatge, Obra Social Caixa Catalunya. Xarxa de Custòdia del Territori. Vic.

Blanco, J.M.; Miranda, D.; Eiriz, I.; Naveira, M.; López, B. \& Bonome, C. (2011). Mariñas-Betanzos sabe a... Guía de productores agroalimentarios de "Mariñas-Betanzos. Asociación de Desenvolvemento Rural "MariñasBetanzos".

Fernández Sánchez, J. \& Pradas Regel, R. 1996. Los Parques Nacionales Españoles. Una aproximación histórica. 482 pp. Red de Parques Nacionales. Organismo Autónomo de Parques Nacionales. Madrid.

García-Borregón Millán, R. (2012). A ordenación dos recursos naturais nos espazos da Rede Natura 2000 de Galicia. Revista Galega de Administración Pública, 44: 161-184.

González Aldama, A. (1982). La ordenación del territorio en relación con los espacios protegidos. En: de Viedma, M.G.; Ortuño, F.; Fernández Tomás, J. G. \& Aboal, J. L. (Eds.). Planificación y Gestión de Espacios Naturales Protegidos: 73-85. Escuela Técnica Superior de Ingenieros de Montes. Fundación Conde del Valle de Salazar. Madrid.

Hernández-Pacheco, E. (1917). Nota sobre el reciente decreto de creación de parques nacionales. Boletín de la Real Sociedad Española de Historia Natural, 17: 149 150.

Hernández-Pacheco, E. (1933). La Comisaría de Parques Nacionales y la Protección a la Naturaleza en España. Guías de los Sitios Naturales de Interés Nacional, $n^{\circ} 3.55$ pp. Comisaría de Parques Nacionales. Ministerio de Agricultura. Madrid.

ICONA (1981). El sistema español de parques nacionales y reservas equivalentes. $57 \mathrm{pp}$. Instituto Nacional para la Conservación de la Naturaleza. Madrid.

Jorge Guille, J. (2014). La custodia del territorio como instrumento de preservación ambiental y desarrollo socioeconómico. Revista Catalana de Dret Ambiental, 5(2): 1 - 49 .

López Ramón, F. (1980). La conservación de la naturaleza: los espacios naturales protegidos. $436 \mathrm{pp}$. Studia Albornotiana, 44. Real Colegio de España. Bolonia. 
Mata Olmo, R. (1992). Los orígenes de la política de espacios naturales protegidos en España: la relación de "sitios notables" de los distritos forestales (1917). En. Cabero Diéguez et al. (Eds.) : El medio rural español, Cultura, paisaje y naturaleza: 1067-1077. Ministerio de Agricultura, Pesca y Alimentación. Ediciones Universidad de Salamanca.

Marcide Odriozola, I. \& Basanta, P. (1944). Plan de intensificación inmediata para el desarrollo de la repoblación forestal hasta conseguir un mínimo de 5.000 hectáreas anuales pro provincia. Desarrollo de la industria de la madera. Ponencia Provincial num. 1 - Pontevedra. Congreso Agrícola de Galicia. Jefatura Provincial del Movimiento. Ediciones de la Delegación Provincial de Educación popular de La Coruña. Imprenta Moret. La Coruña.

Mulero Mendigorri, A. (2002). La protección de espacios naturales en España. 309 pp. Mundi-Prensa. Madrid.

Ortuño Medina, F. (1977). La política de Parques Nacionales en España. Parques, 2 (1): 12-14.

Paül Carril, V. (2009). El turismo en el Parque Natural do Invernadeiro. Situación heredada y perspectivas de cambio. Cuadernos de turismo, 24: 135-168.

Pidal y Bernaldo de Quirós, P. (1917a). Lo que es un Parque Nacional y el Parque Nacional de Covadonga. 18 pp. Imp. Ramona Velasco. Madrid.

Pidal y Bernaldo de Quirós, P. (1917b). Filosofía de los Parques Nacionales. España Forestal, 3 (25): 68-69.

Ramil Rego (Dir.) (2008). Plan de Ordenación dos Recursos Naturais do Parque Natural da Baixa Limia - Serra do Xurés. 185 pp. Dirección Xeral de Conservación da Natureza. Consellería de Medio Ambiente e Desenvolvemento Sostible. Xunta de Galicia. LIFENaturaleza. IBADER. GI-1934-TTB. Lugo.

Ramil Rego, P. \& Crecente Maseda, R. (Dirs.) (2005). Plan de Ordenación de los Recursos Naturales. Espacio Natural Protegido Parga-Ladra-Támoga. 2 Tomos. Dirección Xeral de Conservación da Natureza. Consellería de Medio Ambiente. Xunta de Galicia. LIFE-Naturaleza. IBADER. GI-TTB-EPS. Lugo.

Ramil-Rego, P \& Ferreiro da Costa, J. (2010). Áreas protexidas: século e medio de políticas e actuacións de conservación da Biodiversidade. A situación en Galiza. En: Reflexións en torno ao medio rural: 71-79. Fundación Vicente Risco. Ourense.

Ramil Rego, P.; Rodríguez, M.A.; Rubinos, M.; Ferreiro, J., Hinojo, B.; Blanco, J.M.; Sinde, M., Gómez-Orellana, L.; Díaz, R.; Martínez, S. \& Muñoz, C. (2005). La expresión territorial de la biodiversidad. Paisajes y hábitats. Recursos Rurais Serie Cursos, 2: 109-128.
Ramil Rego, P. \& Rigueiro Rodríguez, A. (Dirs.) (2008).Plan de Ordenación dos Recursos Naturais do Parque Natural dos Ancares. 205 pp. Dirección Xeral de Conservación da Natureza. Consellería de Medio Ambiente e Desenvolvemento Sostible. Xunta de Galicia. LIFENaturaleza. IBADER. GI-1934-TTB. Lugo.

Ramil Rego, P.; Rodríguez Guitián, M.A.; Hinojo Sánchez, B.A.; Rodríguez González, P.M.; Ferreiro da Costa, J.; Rubinos Román, M.; Gómez-Orellana, L.; de Nóvoa Fernández, B. ; Díaz Varela, R.A.; Martínez Sánchez, S. \& Cillero Castro, C. (2008a). Os Hábitats de Interese Comunitario en Galicia. Descrición e Valoración Territorial. Monografías do Ibader. Universidade de Santiago de Compostela. Lugo.

Ramil Rego, P.; Rodríguez Guitián, M.A.; Ferreiro da Costa, J.; Rubinos Román, M.; Gómez-Orellana, L.; de Nóvoa Fernández, B.; Hinojo Sánchez, B.A.; Martínez Sánchez, S.; Cillero Castro, C.; Díaz Varela, R.A.; Rodríguez González, P.M. \& Muñoz Sobrino, C. (2008b). Os Hábitats de Interese Comunitario en Galicia. Fichas descritivas. Monografías do Ibader. Universidade de Santiago de Compostela. Lugo.

Ramil Rego, P.; Ferreiro da Costa, J.; de Nóvoa Fernández, B.; Hinojo Sánchez, B. \& Rubinos Román, M. A. (2011). Evaluación de servicios de los ecosistemas y biodiversidad en las Reservas de Biosfera de Galicia. En: Las Reservas de Biosfera como estrategia territorial de sostenibilidad: 11-28. Servicio de Publicacións e Intercambio Científico. Universidade de Santiago de Compostela. Lugo.

Ramil Rego, P.; Crecente Maseda, R.; Ferreiro da Costa, J.; Hinojo Sánchez, B.A.; de Nóvoa Fernández, B.; Rubinos Román, M. \& Rodríguez Guitián, M. A. (2012). Plan Director da Rede Natura 2000 de Galicia. Documento de síntese. 233 pp. GI-1934-TB. Universidade de Santiago de Compostela. Dirección Xeral de Conservación da Natureza. Xunta de Galicia. Santiago de Compostela.

Rigueiro Rodríguez, A.; Ramil Rego, P.; Crecente Maseda, R. \& Rodríguez Guitián, M. A. (2005). Plan de Ordenación de los Recursos Naturales. Espacio Natural Protegido Os Ancares - O Courel. 2 Tomos. Dirección Xeral de Conservación da Natureza. Consellería de Medio Ambiente. Xunta de Galicia. Escola Politécnica Superior. Lugo. 